\title{
Assessment of Managed Aquifer Recharge through Modeling-A Review
}

\author{
Jana Ringleb *, Jana Sallwey and Catalin Stefan \\ Department of Hydrosciences, Technische Universität Dresden, 01062 Dresden, Germany; \\ jana.sallwey@tu-dresden.de (J.S.); catalin.stefan@tu-dresden.de (C.S.) \\ * Correspondence: jana.ringleb@tu-dresden.de; Tel.: +49-3501-530046 \\ Academic Editors: Pieter J. Stuyfzand and Niels Hartog \\ Received: 16 August 2016; Accepted: 30 November 2016; Published: 7 December 2016
}

\begin{abstract}
Managed aquifer recharge (MAR) is the purposeful recharge of an aquifer for later recovery or environmental benefits and represents a valuable method for sustainable water resources management. Models can be helpful tools for the assessment of MAR systems. This review encompasses a survey and an analysis of case studies which apply flow and transport models to evaluate MAR. The observed modeling objectives include the planning or optimization of MAR schemes as well as the identification and quantification of geochemical processes during injection, storage and recovery. The water recovery efficiency and the impact of the injected water on the ambient groundwater are further objectives investigated in the reviewed studies. These objectives are mainly solved by using groundwater flow models. Unsaturated flow models, solute transport models, reactive geochemical models as well as water balance models are also frequently applied and often coupled. As each planning step to setup a new MAR facility requires cost and time investment, modeling is used to minimize hazard risks and assess possible constraints of the system such as low recovery efficiency, clogging and geochemical processes.
\end{abstract}

Keywords: managed aquifer recharge; modeling; groundwater management; unsaturated zone; ASR

\section{Introduction}

The rising water demand worldwide, caused by climate change, urbanization and population growth, poses increasing stress on groundwater as a resource [1,2]. Especially in arid or semi-arid regions the natural recharge is often not enough to meet the local water demand leading to over-exploitation of the groundwater resource and as a consequence to decreasing water tables and increasing salinization [3]. The storage of water in surface reservoirs is widespread but it has several disadvantages such as high evaporation losses, high land area requirements, sediment accumulation, the possibility of structural failure and high vulnerability to contamination $[1,4,5]$. An alternative to surface storage is storing excess water underground during periods of low demand or high availability to use it later in times of shortages $[4,6,7]$. In contrast to other recharge types such as natural or incidental recharge, managed aquifer recharge (MAR) is the intentional recharge of water into aquifers for future recovery or environmental benefits [1,3]. Incidental or unintentional recharge implies recharging the aquifer coincidentally by undertaking activities not directly designed to enhance recharge such as excess irrigation or leakage from water systems $[1,8]$. The main objective of MAR is to increase groundwater storage to overcome the temporal imbalance between local water demand and availability thus securing drinking or irrigation water supply at any time of the year $[1,3]$. Other objectives include the reduction of saltwater intrusion in coastal aquifers, prevention of land subsidence, improvement of the source water quality through Soil Aquifer Treatment (SAT) and avoidance of direct potable reuse of treated wastewater by an underground passage $[1,3]$. Water sources include surface water from rivers or lakes, stormwater runoff and reclaimed water $[1,9,10]$. 
Before this water is recharged to an aquifer a pretreatment might be necessary depending on the source water quality, the contaminant attenuation through the soil passage, the native groundwater quality and the intended use of the recovered water.

Subject to the local conditions, a wide range of MAR methods can be used to recharge an aquifer [8]. Usually five main MAR techniques are distinguished: well, shaft and borehole recharge; spreading methods; induced bank filtration; in-channel modifications; and rainwater and runoff harvesting [11,12] (Table 1). Recharge by well, shaft and borehole includes MAR methods that recharge directly into the aquifer which is often overlain by low permeability surface structures [11]. Spreading methods are applied at ground level where the water is infiltrated through permeable surface into the unsaturated zone. Induced bank filtration covers infiltration of surface water through river, lake or dune sediments caused by well pumping [8,11]. In-channel modifications are obstructions built directly in the stream network to temporarily store stormwater and enhance infiltration into river sediments [8]. Rainwater and runoff harvesting comprises the gathering and infiltration of surface or roof runoff by barriers, bunds and trenches $[9,11]$. It should not be confused with other MAR methods which often use stormwater as a water source. For detailed descriptions of the aforementioned MAR techniques see Dillon [3], Gale [8] or Hannappel et al. [11]. The classification of MAR techniques in this paper is based on the classification system developed by the International Groundwater Resources Assessment Centre [13], with the exception that ASR and ASTR are joint. In addition to these established MAR methods, there is a rising interest in new strategies for water banking which includes using agricultural land for surface spreading methods outside the irrigation season [14].

Table 1. Managed Aquifer Recharge (MAR) classification system stating five main methods and associated specific MAR methods, adapted from International Groundwater Resources Assessment Centre [13].

\begin{tabular}{|c|c|c|}
\hline & Main MAR Methods & Specific MAR Methods \\
\hline \multirow{3}{*}{$\begin{array}{l}\text { Techniques referring } \\
\text { primarily to getting } \\
\text { water infiltrated }\end{array}$} & $\begin{array}{l}\text { Well, shaft and } \\
\text { borehole recharge }\end{array}$ & $\begin{array}{l}\text { Aquifer Storage and Recovery (ASR)/ Aquifer } \\
\text { Storage, Transfer and Recovery (ASTR) } \\
\text { Shallow well/shaft/pit infiltration }\end{array}$ \\
\hline & Spreading methods & $\begin{array}{l}\text { Infiltration ponds \& basins } \\
\text { Flooding } \\
\text { Ditch, furrow, drains } \\
\text { Irrigation }\end{array}$ \\
\hline & Induced bank infiltration & $\begin{array}{l}\text { River/lake bank filtration } \\
\text { Dune filtration }\end{array}$ \\
\hline \multirow{2}{*}{$\begin{array}{l}\text { Techniques referring } \\
\text { primarily to intercepting } \\
\text { the water }\end{array}$} & In-channel modifications & $\begin{array}{l}\text { Recharge dams } \\
\text { Subsurface dams } \\
\text { Sand dams } \\
\text { Channel spreading }\end{array}$ \\
\hline & Runoff harvesting & $\begin{array}{c}\text { Rooftop rainwater harvesting } \\
\text { Barriers and bunds } \\
\text { Trenches }\end{array}$ \\
\hline
\end{tabular}

Despite the apparent simplicity of MAR approaches and their large implementation worldwide [15], the complexity of site-specific hydrogeological conditions and the processes occurring at various scales combined with different objectives require a very good understanding of the system's response to the proposed measures. The characterization of the system including heterogeneities such as preferential flow paths is best investigated by field experiments, e.g., [16,17]. Laboratory experiments are used to investigate occurring processes in detail but are limited in representing boundary conditions and scale-related issues may occur. On the other hand, modeling can be used for scenario analysis and future predictions to compare different MAR techniques and operational schemes. Despite adaptive approaches for example using trial and error, modeling is a valuable tool 
to estimate the feasibility of a MAR method at a given location. Given its flexibility, a model-based preliminary assessment is often recommended prior to pilot field experiments [17,18]. Even though building up a calibrated model takes up time and requires a detailed data set, the variety of possible applications such as scenario and sensitivity analyses can make the efforts worthwhile. However, modeling does not always lead to success and despite that fact, failures are hardly ever published. Some countries including Australia and the USA implemented guidelines that specifically regulate the requirements for risk assessment of new MAR facilities and advise the application of modeling during the planning phase $[19,20]$.

So far, only Kloppmann et al. [18] published a summary of the application of groundwater models for the estimation and optimization of the performance of MAR schemes. They focus on different planning phases of a MAR system including site selection, design and operation and give an overview of data requirements and model selection.

Nevertheless, no review paper is published yet which analyzes model applications specifically focusing on each MAR method and comprises past areas of application and the choice of modeling software for each technique. Focus is not only restricted to groundwater models but also regards analytical and numerical flow and transport models considering, besides groundwater, also other components of the hydrological cycle. For this reason, case studies were collected from reviewed articles, scientific reports and conference proceedings, all written in English language. The search for publications was carried out via search engines and online databases but also reference lists of already located publications were screened. The search was restricted to MAR and artificial recharge. Only flow and transport models were included. Despite the scrupulous search, it was difficult to track all publications in the field and further relevant modeling studies likely exist. Data was analyzed regarding the evaluated main and specific MAR techniques, the model tools applied and the modeling objectives. Furthermore, the country of the field site or whether the publication covers a laboratory experiment or theoretical analysis was noted. The analysis helps to identify general trends in the utilization of models for MAR assessment. The overview on the presented software tools and their classification by model and MAR type can further ease the search of a suitable computer code and can thus be used as a general reference. Furthermore, modeling studies were reviewed regarding the different MAR methods to allow a more detailed look into modeling objectives and applications in the various fields of MAR. Elaborative information is given on what kind of model approaches and software tools can be applied during the planning stage, the first pilot experiments or the optimization of existing facilities depending on the site-specific issues. The review covers most processes occurring during MAR applications and discusses the influence of various operation and site-specific parameters on the overall system efficiency. While this is comprehensively discussed in the literature, the added value of the review is that it provides the reader also with the adequate tools for the quantitative and qualitative assessment.

The overall objective of the present paper is thus the introduction and evaluation of different modeling approaches which are used to assess MAR schemes dependent on site-specific conditions and applied MAR method through a structured review of most commonly used software codes and tools.

\section{Analysis of Managed Aquifer Recharge Modeling Case Studies}

Overall, 216 studies dealing with flow and transport modeling of MAR from 37 countries were collected from widely available literature published between 1985 and 2015 (Table S1). The papers included 188 modeling studies which evaluate field-scale MAR schemes or sites, 10 modeling studies which evaluate laboratory experiments and 18 assessing theoretical issues. Most studies were carried out in the USA (45 literature studies), Australia (39), The Netherlands (20) and India (13). 


\subsection{Modeled Managed Aquifer Recharge Methods}

The majority of modeling studies were performed for well, shaft and borehole recharge (57\%) and spreading methods (29\%) (Figure 1). A recently published global MAR inventory shows that these are also the two most common MAR techniques applied worldwide [15,21]. However, the comparison of the global MAR inventory with this study reveals that spreading methods are the most common MAR techniques worldwide whereas most of the modeling studies identified were conducted for well, shaft and borehole recharge. As this method is technically demanding and there is a high need for information during the planning of the system, it is often accompanied by modeling. Only a few case studies are published which deal with modeling of rainwater and runoff harvesting facilities [22,23]. This method is frequently used in rural areas and is not technically demanding. Thus, it is regularly not accompanied by scientific or monitoring studies (in contrast to harvesting stormwater which is injected into wells or infiltrated via infiltration ponds) [22]. Models are mostly applied for the MAR subtypes ASR/ASTR (52\%), infiltration ponds and basins (23\%) and induced bank filtration (6\%).

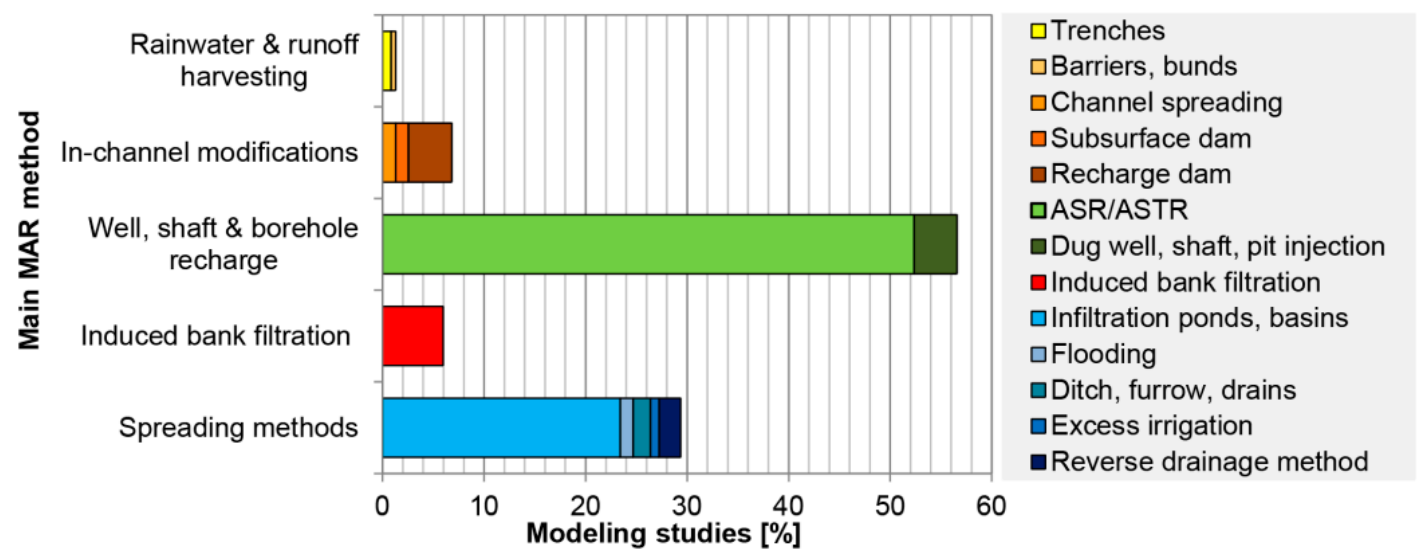

Figure 1. Distribution of modeling studies (\%) for the main MAR techniques and MAR subtypes used (literature studies may involve multiple MAR techniques).

\subsection{Survey of Applied Models}

Various models are applied to evaluate MAR. For this analysis models were grouped into five categories namely groundwater flow, unsaturated flow, solute transport, reactive transport and watershed or water balance models. Groundwater flow models depict the saturated soil zone and are mainly based on Darcy's law [24] whereas unsaturated flow models mostly apply the Richards' equation [25]. Non-reactive or solute transport models include solute transport codes where advection, dispersion, diffusion, sorption and decay are considered. Reactive transport models are more complex and include geochemical and biogeochemical reactions. Watershed or water balance models include the surface water and partly apply an integrated water resource management approach.

One of the earliest applications of modeling for the assessment of MAR dates back to 1985 [26,27]. An increase in the number of model applications is observed from 1996 to 2000 reflecting amongst others the fast development and public availability of computer capacities and the increasing use of MAR worldwide [21] (Figure 2). The total number of publications continues to increase till the end of the study period (2015), with groundwater flow models being the most frequently applied model type during the entire investigated period. Since 2006, the number of publications of groundwater flow, unsaturated flow as well as water balance and watershed models keeps increasing. 


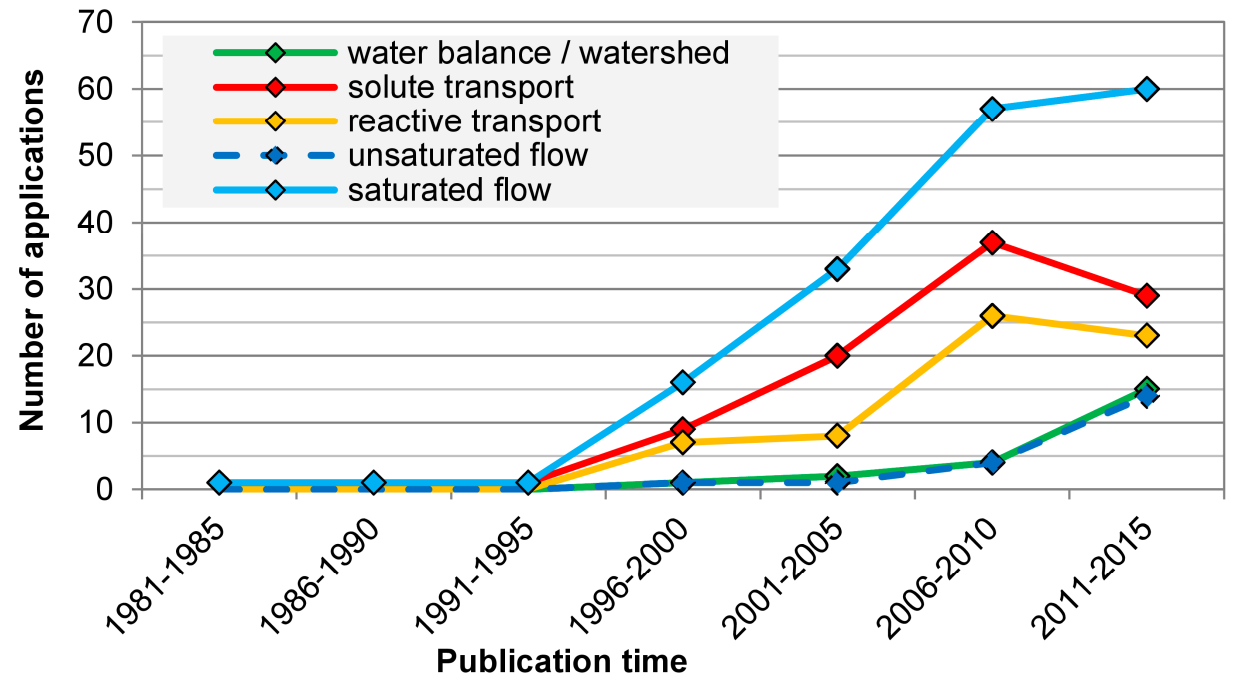

Figure 2. Historical development of different model types (literature studies may involve multiple or combine different model types).

In the reviewed literature studies various software tools were applied which model flow and transport (Table 2). A number of software tools were specifically developed for MAR applications while others are also used in general hydrogeological studies. Within the first category, the NASRI-BF Simulator assists in the design and operation of bank filtration sites and allows for a first assessment of the feasibility and conditions of a proposed site [28]. EL-ASR is an ASR adjusted derivative of the transport model EASY-LEACHER and able to account for various water quality issues which can arise during ASR [29]. Five major clogging mechanisms namely physical, biological, chemical clogging as well as the formation of gas and compaction were implemented into a numerical three-dimensional finite element code called CLOG [30]. It can assist in the design and operation of a MAR facility helping to prevent clogging and consequently improving the efficiency of the system [30]. Besides analytical and numerical models, simple empirical tools were developed particularly for the utilization as screening tools, e.g., ASRRI and the ASR Performance Index. The software ASRRI (ASR Risk Index) is a screening tool to predict the potential for contaminant attenuation during ASR and ASTR [31]. The ASR Performance Index evaluates whether lateral flow, density effects and dispersive mixing have negative effects on the recovery efficiency in saline or brackish aquifers [32].

The majority of models applied are not specifically developed for MAR applications. The most commonly used groundwater flow model is MODFLOW [33]. Further frequently applied codes for saturated flow modeling include FEFLOW [34], SEAWAT [35], HST3D [36] and PHAST [37]. Frequently applied unsaturated flow models include MARTHE [38], HYDRUS [39] and MIKE-SHE [40]. For solute transport modeling FEFLOW, MT3DMS [41], SEAWAT and CXTFIT [42] are used repeatedly. Reactive transport modeling is conducted mainly by using PHREEQC [43], MT3DMS, PHT3D [44] and EASY-LEACHER [45]. For the category water balance and watershed models only WaterCress [46] was applied in more than one case study. 
Table 2. List of modeling software tools which were applied more than once in literature studies arranged in alphabetical order including the number of applications. The main MAR methods analyzed and the model types covered by the listed software tools are marked with " $x$ " (note that some software tools can also be feasible for other MAR methods and might be applicable to further model types).

\begin{tabular}{|c|c|c|c|c|c|c|c|c|c|c|c|}
\hline \multirow[b]{2}{*}{ Software } & \multirow[b]{2}{*}{$\begin{array}{c}\text { Number of } \\
\text { Applications }\end{array}$} & \multicolumn{5}{|c|}{ Model Type } & \multicolumn{5}{|c|}{ MAR Method } \\
\hline & & $\begin{array}{l}\text { Saturated } \\
\text { Flow }\end{array}$ & $\begin{array}{l}\text { Unsaturated } \\
\text { Flow }\end{array}$ & $\begin{array}{c}\text { Water Balance/ } \\
\text { Watershed }\end{array}$ & $\begin{array}{c}\text { Solute } \\
\text { Transport }\end{array}$ & $\begin{array}{l}\text { Reactive } \\
\text { Transport }\end{array}$ & $\begin{array}{l}\text { Well, Shaft } \\
\text { and Borehole } \\
\text { Recharge }\end{array}$ & $\begin{array}{l}\text { Spreading } \\
\text { Methods }\end{array}$ & $\begin{array}{l}\text { In-Channel } \\
\text { Modifications }\end{array}$ & $\begin{array}{c}\text { Induced } \\
\text { Bank } \\
\text { Filtration }\end{array}$ & $\begin{array}{c}\text { Rainwater } \\
\text { and Runoff } \\
\text { Harvesting }\end{array}$ \\
\hline CFEST [47] & 2 & $x$ & & & $x$ & & $x$ & & & & \\
\hline COMSOL [48] & 2 & $\mathrm{x}$ & $\mathrm{x}$ & & $\mathrm{x}$ & & $\mathrm{x}$ & $\mathrm{x}$ & & & \\
\hline CXTFIT [42] & 6 & & & & $\mathrm{x}$ & & $\mathrm{x}$ & $\mathrm{x}$ & & $\mathrm{x}$ & \\
\hline EASY-LEACHER [45] & 5 & & & & $\mathrm{x}$ & $\mathrm{x}$ & $\mathrm{x}$ & $\mathrm{x}$ & & & \\
\hline Eclipse [49] & 3 & $\mathrm{x}$ & & & $\mathrm{x}$ & & $\mathrm{x}$ & & & & \\
\hline FEFLOW [34] & 17 & $\mathrm{x}$ & $\mathrm{x}$ & & $\mathrm{x}$ & & $\mathrm{x}$ & & $\mathrm{x}$ & $\mathrm{x}$ & \\
\hline HST3D [36] & 3 & $\mathrm{x}$ & & & $\mathrm{x}$ & & $\mathrm{x}$ & & & & \\
\hline HYDRUS [39] & 3 & $\mathrm{x}$ & $\mathrm{x}$ & & & & $\mathrm{x}$ & & & & \\
\hline MARTHE [38] & 4 & $\mathrm{x}$ & $\mathrm{x}$ & & $\mathrm{x}$ & & $\mathrm{x}$ & $\mathrm{x}$ & & & \\
\hline MIKE-11 [50] & 2 & & & $\mathrm{x}$ & & & $x$ & & $x$ & & \\
\hline MIKE-SHE [40] & 3 & $\mathrm{x}$ & $\mathrm{x}$ & & & & $\mathrm{x}$ & $\mathrm{x}$ & $\mathrm{x}$ & & \\
\hline MOCDENS3D [51] & 2 & $\mathrm{x}$ & & & $\mathrm{x}$ & & & $\mathrm{x}$ & & & \\
\hline MODFLOW [33] & 73 & $\mathrm{x}$ & & & & & $\mathrm{x}$ & $\mathrm{x}$ & $\mathrm{x}$ & $\mathrm{x}$ & \\
\hline MT3DMS (MT3D) [41] & 16 & & & & $\mathrm{x}$ & $\mathrm{x}$ & $\mathrm{x}$ & $\mathrm{x}$ & & $\mathrm{x}$ & \\
\hline NASRI-BF Simulator [28] & 3 & $\mathrm{x}$ & & & & & & & & $\mathrm{x}$ & \\
\hline PHAST [37] & 2 & $\mathrm{x}$ & & & $\mathrm{x}$ & $\mathrm{x}$ & $\mathrm{x}$ & & & & \\
\hline PHREEQC [43] & 30 & & & & & $\mathrm{x}$ & $\mathrm{x}$ & $\mathrm{x}$ & & $\mathrm{x}$ & \\
\hline PHT3D [44] & 13 & & & & $\mathrm{x}$ & $\mathrm{x}$ & $\mathrm{x}$ & $\mathrm{x}$ & & & \\
\hline SEAWAT [35] & 11 & $\mathrm{x}$ & & & $\mathrm{x}$ & & $\mathrm{x}$ & $\mathrm{x}$ & & & \\
\hline SUTRA [52] & 5 & $x$ & & & $\mathrm{x}$ & & $\mathrm{x}$ & $\mathrm{x}$ & $\mathrm{x}$ & & \\
\hline SWIFT [53] & 2 & $\mathrm{x}$ & & & $\mathrm{x}$ & & $\mathrm{x}$ & & & & \\
\hline TOUGH2 [54] & 2 & $\mathrm{x}$ & $\mathrm{x}$ & & $\mathrm{x}$ & $\mathrm{x}$ & & $\mathrm{x}$ & & & \\
\hline WaterCress [46] & 2 & & & $\mathrm{x}$ & & & $\mathrm{x}$ & $\mathrm{x}$ & & & \\
\hline
\end{tabular}




\subsection{Modeling Objectives}

The objectives for conducting a modeling study are manifold and for this paper they were classified into 13 categories. Literature studies comparing different proposed recharge methods as well as sites show that flow modeling can help to select a MAR method and evaluate its advantages and disadvantages at a proposed location $[6,55,56]$. Modeling is usually performed during the approval or planning phase of a MAR system to evaluate its feasibility at a suggested site (Feasibility). Further investigations may assess the optimal design of the system (Design) and whether it will meet performance objectives prior to the construction of field-scale systems $[4,17]$. The optimization of MAR systems (Optimization) which includes assessing optimal infiltration and recovery schedules is another aspect of MAR planning. Modeling studies are also conducted to quantify the recovery efficiency (Recovery efficiency) which is the amount of water that can be recovered with desired water quality and the residence time (Residence time) of infiltrated water. The migration of injected water and the mixing with natural groundwater are thus calculated to quantify the storage or infiltration capacity of a MAR site.

Modeling studies focusing on geochemical processes (Geochemical processes) during the MAR application mainly analyze the quality of recovered water. Metal release and mobilization, nutrient removal and micropollutant breakthrough are the main issues evaluated. The fate of pathogens, nutrients and chemicals such as disinfection-by-products during the soil passage are examined. Another significant aspect is clogging which decreases the infiltration capacity of a MAR scheme (Clogging). Studies on general assessment of water quality (Water quality) might consider water quality changes of the injected water, the ambient groundwater or the recovered water. Soil aquifer treatment specifically focuses on water quality improvements due to the oxidation and microbial degradation of organic matter during the soil passage through the unsaturated zone (Soil aquifer treatment).

Modeling the impact on groundwater generally depicts the resulting groundwater level changes and the area of impact when MAR is applied (Groundwater management). In addition, sustainable river discharge due to economic or environmental restrictions is evaluated (River flows). Risk Assessment is a method to evaluate possible hazards and associated risks such as pathogen breakthrough which can arise during MAR (Risk assessment). In coastal areas, modeling is also used to assess the effect of applying MAR against saltwater intrusion (Saltwater intrusion).

The reasons for model applications cannot be generalized for the individual MAR types. However, some application trends can be derived from the survey and are more closely discussed in the Sections 2.3.1-2.3.5. The different MAR methods are described separately as each method poses diverse requirements on the modeling study and various objectives are pursued.

\subsubsection{Well, Shaft and Borehole Recharge}

During well, shaft and borehole recharge water is injected either directly into the aquifer or infiltrated by gravity into the unsaturated soil zone. Various hydrogeological and operational parameters such as the groundwater gradient, the aquifer heterogeneity and the recharged water volume influence the success of the system. Thus, injecting water into an aquifer is quite complex and its general feasibility is often investigated by applying a numerical groundwater flow model [7,57-64] (Figure 3).

Not only various design scenarios such as well locations and well spacing but also operational management options such as pumping and injections rates are being tested and optimized with the help of simulations $[7,17,57,63-68]$. Water management models are applied to assist in the cost-effective planning and design of reliable subsurface infiltration systems $[7,69]$. Scenario analysis incorporating projections of climate change and effects of urbanization into MAR scheme design was also addressed by modeling [46]. 


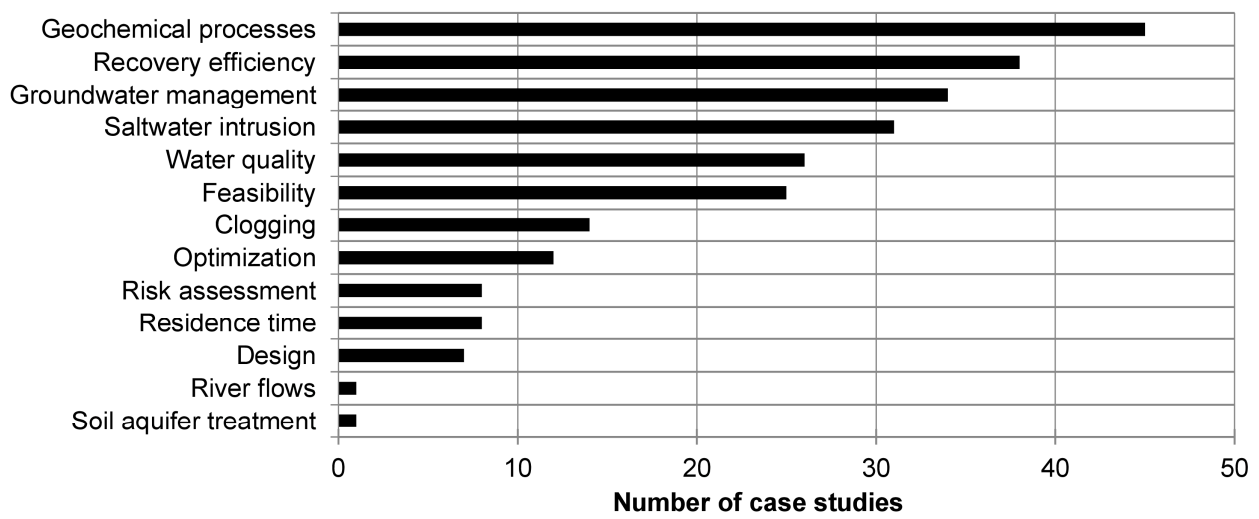

Figure 3. Distribution of well, shaft and borehole recharge modeling studies by objective (literature studies may involve multiple modeling objectives).

Quantifying the resulting groundwater levels and the spreading of injected water in the aquifer is a task often solved by groundwater flow modeling [7,55,70-74]. In addition, a groundwater flow model can help to estimate the quantity of water which can be stored underground [71,75-77], the impact of ASR on nearby production wells $[72,78,79]$ and the impact of ASR on possible land subsidence [80]. When infiltrating into coastal aquifers the extent of seawater intrusion and the location of the freshwater-saltwater interface is of special interest and requires the application of density-dependent groundwater flow models [58,81-83].

Groundwater flow and solute transport models were also widely used to examine the influence of hydrogeological and operational parameters on the recovery efficiency $[4,26,27,84-90]$ (Figure 3). Key parameters that have been modeled and that influence the recovery rate are the dispersity of the aquifer $[32,86,88,91]$ and the aquifer heterogeneity $[4,92,93]$ which can be characterized by high variations of permeability or the presence of dual-porosity zones. Modeling these parameters may help to understand the aquifer system and thus adapt the MAR operation scheme. Dual-porosity flow $[4,92-94]$ and density-driven or buoyancy-induced flow $[4,32,83,89,93-99]$ were incorporated into models in order to depict those complex processes. A simple screening tool developed by Ward et al. [32] can help to assess ASR performance in brackish and saline aquifers prior to numerical modeling.

Geochemical processes represent a major challenge as they influence not only the quality of the recovered water but also clogging. Their occurrence is caused by the differences in the chemical composition of injection water and ambient groundwater or water-rock interactions. Therefore, the modeling objective assessed the most for well, shaft and borehole recharge is geochemical processes (Figure 3). Reactive transport models are applied to identify the geochemical processes that take place during well injection and recovery [2,100-105]. Besides complex numerical codes, analytical transport models like EASY-LEACHER can be used to evaluate geochemical processes during deep well injection $[29,45,106]$. Pyrite oxidation is one of the key geochemical reactions identified [107-112] which often leads to mobilization of trace metals or metalloids [107-115]. Other geochemical reactions that could be identified by modeling are the dissolution of fluoride minerals [116] and the acidification in the aquifer [114,115]. Furthermore, scenario simulations were done to test how the dissolution of metals can be controlled [114].

Not only the dissolution of minerals but also their precipitation has been studied by modeling as it can affect the performance of an artificial recharge system by causing chemical clogging [117-123]. The numerical code CLOG has been used to assess different aspects of clogging taking into account the accumulation of suspended solids, bacterial growth, chemical reactions and the generation of gas and compaction [30,124].

Risk assessment tools were used to evaluate the fate of possible organic contaminant hazards during ASR [31,125-130]. Incorporation of biogeochemical reactions can help to quantify bacterial 
influence on the local geochemistry $[131,132]$ and show the removal efficiencies of organic contaminants during successive ASR cycles [133].

About two third of the compiled studies combined several objectives in their modeling study. An overview about the models used more than once for the specific objectives is given in Table 3. It can be stated that MODFLOW (33 applications) and PHREEQC (21 applications) are the most commonly used simulation tools for modeling of well, shaft and borehole recharge.

Table 3. List of models which were applied more than once for the different modeling objectives for the MAR technique well, shaft and borehole recharge.

\begin{tabular}{|c|c|c|}
\hline Modeling Objective & Model Used & References \\
\hline \multirow{3}{*}{ Clogging } & PHREEQC & {$[118-120,123,134,135]$} \\
\hline & PHT3D & {$[103,132,136]$} \\
\hline & CLOG & {$[30,124]$} \\
\hline \multirow{2}{*}{ Design } & FEFLOW & {$[63,64,121]$} \\
\hline & MODFLOW & {$[76,77]$} \\
\hline \multirow{3}{*}{ Optimization } & MODFLOW & {$[7,68,71]$} \\
\hline & WaterCress & {$[46,137]$} \\
\hline & FEFLOW & {$[82,138]$} \\
\hline \multirow{3}{*}{ Feasibility } & MODFLOW & {$[55,57,59,61,65,71,84,139-143]$} \\
\hline & PHREEQC & {$[2,114,144]$} \\
\hline & SEAWAT & {$[83,84]$} \\
\hline \multirow{5}{*}{ Water quality } & PHREEQC & {$[2,7,100,101,110,111,116,134,145]$} \\
\hline & PHT3D & {$[103,104,107-109,126,132,136,144,146]$} \\
\hline & EASY-LEACHER (EL-ASR) & {$[29,45,126]$} \\
\hline & MODFLOW & {$[103,108,132,136]$} \\
\hline & MT3DMS & {$[103,132,136]$} \\
\hline \multirow{7}{*}{ Geochemical processes } & PHREEQC & $\begin{array}{c}{[2,7,100,101,110-112,114,116-121,123,134,} \\
135,144,145,147-149]\end{array}$ \\
\hline & MODFLOW & {$[103,108,132,136,148,150-152]$} \\
\hline & PHAST & {$[102,149,153]$} \\
\hline & PHT3D & {$[103,104,107-109,126,132,136,146]$} \\
\hline & EASY-LEACHER (EL-ASR) & {$[29,45,126]$} \\
\hline & MT3DMS & {$[103,132,136,148]$} \\
\hline & CLOG & {$[30,124]$} \\
\hline \multirow{5}{*}{ Groundwater management } & MODFLOW & {$[55,60,61,72-78,122,154,155]$} \\
\hline & FEFLOW & {$[63,64,82,99,138]$} \\
\hline & HYDRUS 2D & {$[156,157]$} \\
\hline & SEAWAT & {$[83,98]$} \\
\hline & SUTRA & {$[81,158]$} \\
\hline \multirow{8}{*}{ Recovery efficiency } & FEFLOW & {$[32,63,64,95,99,135,159,160]$} \\
\hline & MODFLOW & {$[57,76-78,84,86,92,155,161]$} \\
\hline & SEAWAT & {$[4,7,84,96-98]$} \\
\hline & HST3D & {$[7,89,90]$} \\
\hline & MT3DMS/MT3D & {$[78,84,86,92,161]$} \\
\hline & INTERA & {$[26,27]$} \\
\hline & SUTRA & {$[87,162]$} \\
\hline & PHAST & {$[102,153]$} \\
\hline \multirow{6}{*}{ Saltwater intrusion } & FEFLOW & {$[32,63,64,82,91,95,96,99,121,135,138,159]$} \\
\hline & SEAWAT & {$[4,82-84,92,97,98]$} \\
\hline & SUTRA & {$[81,87,158,162]$} \\
\hline & HST3D & {$[7,89,90]$} \\
\hline & ECLIPSE & {$[66,93]$} \\
\hline & MODFLOW & {$[57,84,155]$} \\
\hline \multirow{3}{*}{ Residence time } & РHT3D & {$[104,126,146]$} \\
\hline & FEFLOW & {$[63,64,96]$} \\
\hline & MODFLOW & {$[152,155]$} \\
\hline
\end{tabular}




\subsubsection{Spreading Methods}

In contrast to other MAR methods, spreading methods require large areas of land as well as certain land use types and geology. Hence, modeling is used to select and evaluate suitable sites for the application of infiltration ponds and basins and to optimize their design [163-169] (Figure 4). The planning of recharge basins as well as the evaluation of different management options is done by modeling [170-174]. Modeling can be used in particular as a supporting tool to design the groundwater monitoring network for infiltration basins and ponds [171,175-179].

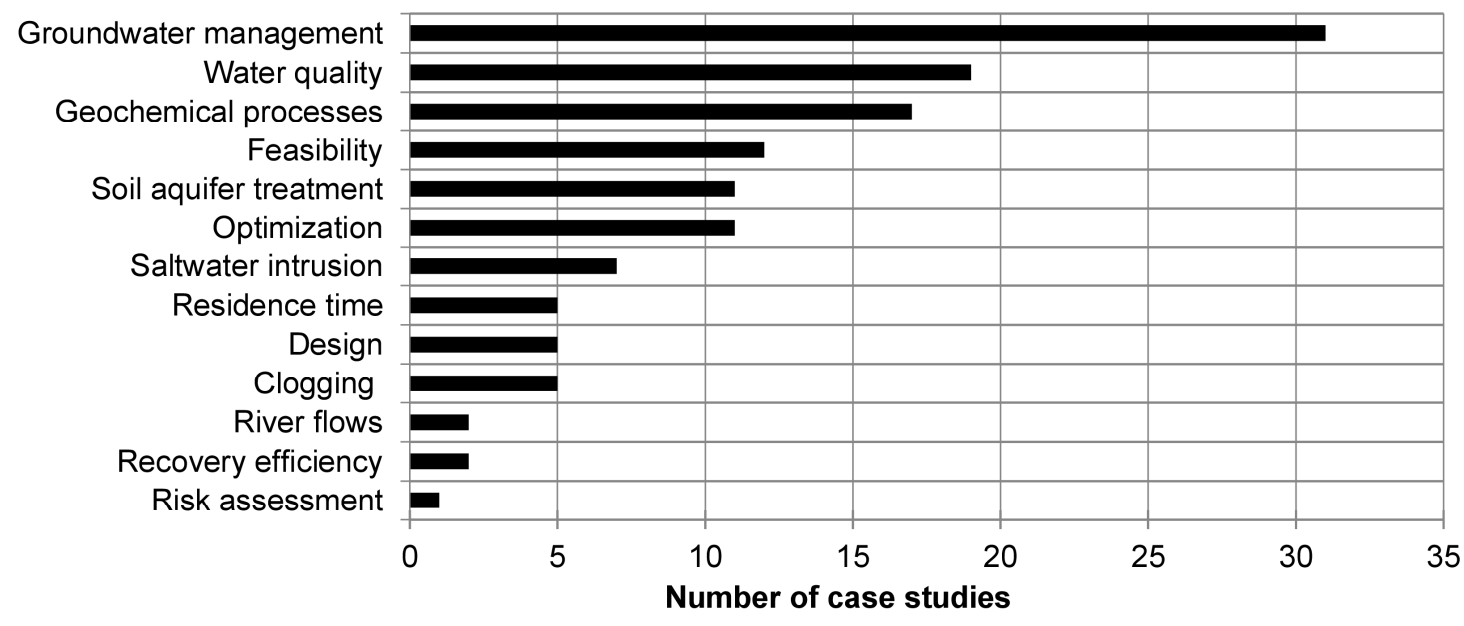

Figure 4. Distribution of spreading methods modeling studies by objective (literature studies may involve multiple modeling objectives).

The impact of the infiltrated water on the groundwater is of interest, especially with regard to the resulting groundwater levels [71,169,174,180-182]. Flow paths and travel times of the infiltrated water in basins and ponds and capture zones of the abstraction wells were often estimated by using groundwater flow models $[171,175,180,183-187]$. Reactive transport modeling helps to identify the occurring geochemical processes, e.g., the interaction of the infiltrated water with the ambient groundwater can be simulated [188,189]. Physical, chemical and biological processes occurring during the infiltration of treated wastewater into the unsaturated soil zone are of special interest as further water purification can be achieved through the soil passage [190-195]. The transport and degradation of organic pollutants like pharmaceuticals or pathogens are studied with transport models [18,131,168,176,196-198]. Consequently, understanding the biogeochemical reactions which occur in the unsaturated and saturated zone is necessary for a thorough risk assessment of complex SAT systems [18]. Modeling can moreover help to predict clogging of surface infiltration systems [30,199-203].

The groundwater flow model MODFLOW is most commonly applied and used to solve almost all identified modeling objectives (Table 4). To evaluate and identify geochemical processes and water quality changes during spreading methods application, PHREEQC, MARTHE, CXTFIT, MT3DMS and EASY-LEACHER are used. 
Table 4. List of models which were applied more than once for the different modeling objectives for the MAR technique spreading methods.

\begin{tabular}{|c|c|c|}
\hline Modeling Objective & Model Used & References \\
\hline Design & MODFLOW & {$[163,204]$} \\
\hline Optimization & $\begin{array}{l}\text { MODFLOW } \\
\text { MT3DMS }\end{array}$ & $\begin{array}{c}{[71,168,174,205,206]} \\
{[168,174]}\end{array}$ \\
\hline Feasibility & $\begin{array}{l}\text { MODFLOW } \\
\text { VS2DI } \\
\text { FEMWATER }\end{array}$ & $\begin{array}{c}{[57,71,163,164,169,182,207]} \\
{[178,179,208]} \\
{[178,179]}\end{array}$ \\
\hline Water quality & $\begin{array}{c}\text { PHREEQC } \\
\text { MODFLOW } \\
\text { MARTHE } \\
\text { MT3DMS } \\
\text { CXTFIT } \\
\text { PHT3D } \\
\text { MOCDENS3D/MOC3D }\end{array}$ & $\begin{array}{c}{[188,193,209,210]} \\
{[131,177,196-198,211,212]} \\
{[18,188,193]} \\
{[177,197,198]} \\
{[202,211,213]} \\
{[130,196]} \\
{[18,212]}\end{array}$ \\
\hline Geochemical processes & $\begin{array}{c}\text { PHREEQC } \\
\text { MODFLOW } \\
\text { MARTHE } \\
\text { EASY-LEACHER } \\
\text { PHT3D }\end{array}$ & $\begin{array}{c}18,188,189,193,210] \\
{[196,202,212]} \\
{[18,188,193]} \\
{[45,200,214]} \\
{[191,196]}\end{array}$ \\
\hline Groundwater management & $\begin{array}{c}\text { MODFLOW } \\
\text { MOCDENS3D/MOC3D } \\
\text { SEAWAT } \\
\text { TOUGH2 } \\
\text { FEMWATER, VS2DI }\end{array}$ & $\begin{array}{c}{[71,142,163,164,169-171,174,180,} \\
182,205,212,215-217] \\
{[185,212]} \\
{[186,187]} \\
{[181,218]} \\
{[178,179]}\end{array}$ \\
\hline SAT & $\begin{array}{l}\text { PHREEQC } \\
\text { MODFLOW } \\
\text { MARTHE } \\
\text { MT3DMS }\end{array}$ & $\begin{array}{c}{[193,209,210]} \\
{[177,197,211]} \\
{[18,193]} \\
{[177,197]}\end{array}$ \\
\hline Saltwater intrusion & MODFLOW & {$[57,170,171,207]$} \\
\hline Residence time & SEAWAT & {$[186,191]$} \\
\hline River flows & MODFLOW & {$[142,163]$} \\
\hline
\end{tabular}

\subsubsection{Induced Bank Filtration}

Pumping well induced infiltration from a surface water body is commonly conducted to improve the surface water quality by an underground passage. Hence, matters of particular interest in the course of induced bank filtration are to separate flow paths, to determine sources of the bank filtrate and to quantify the leakage water.

Those issues are mainly evaluated by groundwater flow modeling, especially with the help of MODFLOW [219-224] (Table 5). Solute transport modeling is also important but applied models are more diverse, with CTXFIT [42,225], MT3D(MS) [219,220] and PHREEQC [226,227] being the most commonly applied ones.

The NASRI-BF Simulator, a tool specifically designed for induced bank infiltration, allows a first rough estimate of the feasibility of bank filtration and to define the optimal position and number of wells $[28,121]$. Optimization of well design has been also conducted by Schafer [224].

As the improvement of water quality is the main objective of induced bank filtration, most modeling studies found focused on transport modeling. Clogging and its evolution during long-term operation have been modeled and the reduction of hydraulic conductivity was simulated $[219,224]$. Governing biogeochemical processes and redox conditions have been simulated for conceptual column studies [227] as well as field studies [226]. Further studies were undertaken to investigate the fate and transport behavior of contaminants [220,223], organic contaminants [220] as well as pharmaceutics 
and algae toxins $[42,202,225]$ during riverbank filtration. The influence of microbiological activity on the recovered water quality was also modeled [226]. With the evolution of simulation codes, very complex chemical interactions can be studied now such as multispecies biochemical reactions [223]. Being able to simulate complex bio- and geochemical reactions holds great potential for understanding the transport and degradation processes of solutes in the subsurface passage. This will enable MAR scheme operators to manage their sites in a more sustainable and efficient way as they are able to determine flow paths, infiltration sources and travel times of the bank filtrate. The identification of geochemical processes during filtration is especially important as the quality of the abstracted water defines the need for further treatment.

Table 5. Induced bank filtration modeling studies. The following abbreviations are used for the covered modeling objectives: Groundwater management (GM), Residence time (RT), Design (D), Feasibility (F), Recovery efficiency (RE), Water quality (WQ), Geochemical processes (GP), Clogging (C), Optimization $(\mathrm{O})$.

\begin{tabular}{ccccc}
\hline Country * & $\begin{array}{c}\text { Publication } \\
\text { Year }\end{array}$ & Model Used & $\begin{array}{c}\text { Modeling } \\
\text { Objectives }\end{array}$ & Reference \\
\hline Austria & 2006 & MODFLOW, MT3D & GP, C & {$[219]$} \\
Germany & 2006 & PHREEQC & WQ, GP & {$[226]$} \\
Germany & 2006 & MODFLOW-MT3DS, CXTFIT & GP, C & {$[202]$} \\
Germany & 2002 & FEFLOW & RT, RE, C & {$[228]$} \\
Germany & 2014 & MODFLOW, MT3DMS & WQ & {$[220]$} \\
Germany & 2006 & MODFLOW & RT, GM & {$[221]$} \\
Kenya & 2012 & MODFLOW, NASRI Bank Filtration Simulator & F, WQ, GM & {$[222]$} \\
L. E. & 2006 & PHREEQC & GP & {$[227]$} \\
L. E. & 2006 & CXTFIT & WQ, GP & {$[225]$} \\
L. E. & 2006 & CXTFIT & GP & {$[42]$} \\
Malawi & 2012 & MODFLOW, NASRI Bank Filtration Simulator & F, WQ, GM & {$[222]$} \\
T. A. & 2008 & NASRI Bank Filtration Simulator & F, D, O & {$[28]$} \\
USA & 2006 & MODFLOW, PHT3D & GP, C & {$[223]$} \\
USA & 2006 & MODFLOW & RE & {$[224]$} \\
\hline \multicolumn{7}{r}{ Notes: * L. E. = laboratory experiment, T. A. = theoretical analysis. } &
\end{tabular}

\subsubsection{In-Channel Modifications}

Recharge and check dams are built in a river bed to enhance recharge from streams whereas subsurface dams are designed to contain the underground flow raising the water table [13]. In general, the prolongation of the flow length and the residence time achieved by channel spreading increases the recharge to the groundwater.

Groundwater management is the focus of the retrieved case studies for in-channel modifications and MODFLOW is the dominating numerical model used [217,229-231] (Table 6). It has been utilized to test planned recharge structures [230] as well as to adjust existing structures [55] regarding their effect on artificial recharge rates. Simulating the movement of recharged water through the underground helped to increase the knowledge about the overall MAR system [231]. Studies testing different in-channel modification techniques regarding their impact on the groundwater have been conducted for Japan [56] and India [217,229] and showed the potential of modeling for scenario analyses and MAR method selection.

Assessment and prevention of seawater intrusion is another issue that has been studied with the help of modeling $[138,158,232]$. The two-dimensional variable-density flow and solute transport model SUTRA was used in this context $[158,233]$ as well as an integrated water resource management approach using a coupled groundwater and surface water model (FEFLOW and MIKE-11) [138,232]. Optimization of existing MAR facilities under various recharge conditions concerning the reduction of seawater intrusion has been studied in Australia [158,233], China [138] and India [232]. The latter study [232] also concerned the assessment and optimization of future structures. 
Table 6. In-channel modifications modeling studies. The following abbreviations are used for the covered modeling objectives: Groundwater management (GM), seawater intrusion (SI), Optimization (O), Residence time (RT), Design (D), Feasibility (F), Recovery efficiency (RE).

\begin{tabular}{cccccc}
\hline Country & $\begin{array}{c}\text { Publication } \\
\text { Year }\end{array}$ & $\begin{array}{c}\text { Specific MAR } \\
\text { Type }\end{array}$ & Model Used & $\begin{array}{c}\text { Modeling } \\
\text { Objectives }\end{array}$ & References \\
\hline Australia & 2002,2007 & Channel spreading & SUTRA & GM, SI & {$[158,233]$} \\
\hline China & 2012 & Recharge dam & $\begin{array}{c}\text { FEFLOW, MIKE-SHE, } \\
\text { SIWA, WBalMo, MIKE-11 }\end{array}$ & GM, SI, O & {$[138]$} \\
\hline China & 2015 & Recharge dam & FEFLOW & GM & {$[234]$} \\
\hline India & 2014 & Recharge dam & FEFLOW, MIKE-11, NAM & GM, SI & {$[232]$} \\
\hline India & 1998 & Recharge dam & MODFLOW & GM & {$[229]$} \\
\hline India & 2010 & Recharge dam & MODFLOW & GM & {$[217]$} \\
\hline India & 2006 & Recharge dam & $\begin{array}{c}\text { MODFLOW, analytical } \\
\text { spreadsheet model }\end{array}$ & RE & {$[235]$} \\
\hline Italy & 2006 & Recharge dam & MODFLOW & RE & {$[55]$} \\
\hline Japan & 2006 & Subsurface dam & 2D FEM model & D & {$[56]$} \\
\hline Namibia & 2012 & Recharge dam & MODFLOW & GM & {$[230]$} \\
\hline Russia & 2006 & Channel spreading & hydrogeological model & RT, GM & {$[236]$} \\
\hline Turkey & 2012 & Subsurface dam & SEEP/W (2D) & GM, D & {$[237]$} \\
\hline USA & 2012 & Recharge dam & MODFLOW & GM & {$[231]$} \\
\hline Uzbekistan & 2010 & Channel spreading & MODFLOW & F & {$[238]$} \\
\hline
\end{tabular}

\subsubsection{Rainwater and Runoff Harvesting}

Rainwater and runoff harvesting is a cost-effective and easy to apply method to artificially recharge an aquifer. It is widely implemented in rural areas but seldom accompanied by scientific studies to monitor and manage the structures [22]. Modeling studies using water balance models and rainfall-runoff models demonstrate that modeling can be valuable to estimate the contribution of rainwater and runoff harvesting to the local water balance and to evaluate further implementation of recharge structures in a catchment $[22,23]$ (Table 7).

Table 7. Rainwater and Runoff Harvesting modeling studies. The following abbreviations are used for the covered modeling objectives: Groundwater management (GM), Optimization (O).

\begin{tabular}{cccccc}
\hline Country & $\begin{array}{c}\text { Publication } \\
\text { Year }\end{array}$ & $\begin{array}{c}\text { Specific MAR } \\
\text { Type }\end{array}$ & Model Used & $\begin{array}{c}\text { Modeling } \\
\text { Objectives }\end{array}$ & Reference \\
\hline India & 2011 & Trenches & water balance model & GM & {$[22]$} \\
India & 2012 & Trenches & rainfall-runoff model & GM, O & {$[23]$} \\
\hline
\end{tabular}

\section{Discussion}

For this survey, 216 studies published over the past 30 years addressing modeling of MAR have been collected and evaluated. Most modeling studies were conducted in the USA, Australia, The Netherlands and India. A few countries implemented guidelines that regulate the requirements for risk assessment of new MAR facilities [19,20,239,240]. The Australian guidelines explicitly advise the application of groundwater flow, transport and geochemical models on a hazard-specific basis during the investigation and trial phase of a new MAR facility [19]. The standard guidelines published by the American Society of Civil Engineering (ASCE) also propose the use of modeling during the preliminary design or feasibility study [20]. The Mexican regulations for the artificial recharge of treated wastewater require the application of numerical models for determining physical-chemical 
reactions in the unsaturated and saturated zone and the system impact on wellfields as well as phreatic levels [240].

Most modeling studies were conducted for well, shaft and borehole recharge and spreading methods, which are also the most frequently applied methods to recharge an aquifer worldwide. Planning and establishing a MAR scheme at a proposed location includes studying the often complex hydrogeology at the site in order to mitigate hazard risks, such as low recovery efficiencies and clogging that can lead to the failure of the facility. Typical objectives for conducting a modeling study are therefore to optimize and plan the design and operation of MAR facilities and to quantify their impact on the groundwater. The achievable recovery efficiency and possible geochemical processes can be assessed using models to analyze scenarios and minimize the failure risk of a facility. Modeling is further used to predict possible long-term impacts regarding the geochemical processes, the recovery efficiency and the impact on the local groundwater. A specific issue often analyzed by modeling includes the prevention of seawater intrusion through MAR. Modeling studies can reduce laboratory and field work that is otherwise needed. Comparative studies may help to select a MAR method and evaluate its advantages and disadvantages at a proposed location. Modeling of different scenarios may also include: site selection, well-field and monitoring network design and the adjustment of operational parameters. Furthermore, a sensitivity analysis can assist to identify the most important hydrogeological and operational parameters influencing the performance of a MAR system. Best-case and worst-case scenarios can be simulated whose reproduction in field and laboratory experiments can be difficult. Having said this, modeling provides the distinctive possibility to include future climate change, water use and management scenarios into the feasibility study.

Depending on the specific objective and data availability, various models are applied. As this study confirmed, groundwater flow models, which are often combined with solute or reactive transport models, are most widely used for MAR assessment. Furthermore, the publications on unsaturated flow, water balance and watershed models keep increasing. Even though some software tools have been specifically developed for MAR [28-32], mostly non MAR-specific models are being utilized. The reviewed modeling studies show that commonly known modeling tools are mostly sufficient to meet the general needs observed for MAR modeling. These include unsaturated and saturated flow modeling, density-driven modeling and also geochemical modeling. Using well-established tools for MAR modeling such as MODFLOW and PHREEQC is generally of advantage due to their existing wide field of past applications and their comprehensive documentation. Developing MAR specific simulation tools has been driven forwards with regard to processes that are not yet well depicted in the common simulation tools. As clogging is a major concern during MAR application, focus has been set on better representation of clogging processes in simulation tools [30]. Other modeling tools have been developed to aid in the detailed MAR operation design for river bank filtration [28] or ASR [29]. Despite that, sophisticated models which include dual-porosity, account for aquifer heterogeneity or accurately simulate reactive geochemical reactions are required to predict MAR performance more reliable at complex sites $[4,17,88]$. There is a need for holistic model systems integrating not only groundwater but also the unsaturated zone and surface water in order to represent intricate MAR systems such as in-channel modifications. Supplementary studies should be conducted to incorporate biological enhanced reactions into biogeochemical modeling as they occur in complex systems with treated wastewater or stormwater [18].

However, with rising complexity of applied models additional hydrogeological parameters and therefore a more detailed characterization of the study site is required. An accurate determination of site-specific parameters and an uncertainty analysis is important to predict the performance, design and operation of a MAR system more reliably by modeling [241]. As models are only a simplified representation of a complex natural system, many sources of error and uncertainty exist. Sources of uncertainty include the conceptual model, model parameters and uncertainties in observation data [242]. As a result, setting up a modeling study is not always crowned by success. Although hardly any failure in MAR modeling is communicated, some general reasons can be inferred from modeling 
studies not dealing with MAR. Insufficient data availability, incorrect interpretation of available data, wrong conceptualization or oversimplification of a complex system and unsuccessful calibration can lead to the fact, that a modeling study is not further pursued. Especially model calibration, which includes sensitivity analysis, can be very demanding. Models with a high number of parameters often need to be calibrated with the help of inverse modeling and specific tools, such as PEST [243] or UCODE [244]. These tools not only require a reliable calibration dataset but also thorough knowledge about the incorporated mechanisms. Thus, calibration is one of the most time-consuming and complex parts of the modeling approach. Emphasis on this modeling step is, however, of importance as it defines the quality and reliability of the modeling results. Furthermore, calibration helps to evaluate if the representation of the system sufficiently meets the study objectives.

Information required for management decisions like the granting of permissions can be derived from modeling. The California Department of Drinking Water recently published a guideline comparing different approaches for the determination of underground residence time at MAR sites using treated wastewater [245]. Numerical groundwater flow modeling was ranked less reliable than geochemical field approaches such as intrinsic or added tracers [245]. This reflects that it often can be difficult to create reliable models considering the frequently insufficient knowledge about aquifer properties and especially preferential flow paths. In addition, the uncertainties inherent in modeling results and limitations of the model need to be properly communicated so that water managers can interpret the results correctly.

Overall, MAR is a valuable method for the sustainable management of groundwater and is widely applied to restore groundwater resources. Modeling is nowadays integrated into MAR feasibility studies and offers the unique possibility to predict the performance and to decrease the risk of failure of a facility.

Supplementary Materials: The following are available online at www.mdpi.com/2073-4441/8/12/579/s1, Table S1: Database of modeling MAR case studies. List of general and specific MAR type, model type, models used, specific and general modeling objectives and reference.

Acknowledgments: This study was supported by the German Federal Ministry of Education and Research (BMBF), grant No. 01LN1311A (Junior Research Group "INOWAS"). We acknowledge support by the German Research Foundation and the Open Access Publication Funds of the TU Dresden. We thank three anonymous reviewers for their comments that led to a substantial improvement of this work.

Author Contributions: Jana Ringleb collected the case studies, conducted the data analysis and mainly wrote the paper. Jana Sallwey helped with the collection of case studies and the preparation as well as the revision of the review. Catalin Stefan contributed with advice, discussions und revisions.

Conflicts of Interest: The authors declare no conflict of interest.

\section{References}

1. Bouwer, H. Artificial recharge of groundwater: Hydrogeology and engineering. Hydrogeol. J. 2002, 10, 121-142. [CrossRef]

2. Vanderzalm, J.L.; Page, D.W.; Barry, K.E.; Dillon, P.J. A comparison of the geochemical response to different managed aquifer recharge operations for injection of urban stormwater in a carbonate aquifer. Appl. Geochem. 2010, 25, 1350-1360. [CrossRef]

3. Dillon, P. Future management of aquifer recharge. Hydrogeol. J. 2005, 13, 313-316. [CrossRef]

4. Maliva, R.G.; Guo, W.; Missimer, T.M. Aquifer Storage and Recovery: Recent Hydrogeological Advances and System Performance. Water Environ. Res. 2006, 78, 2428-2435. [CrossRef] [PubMed]

5. Minsley, B.J.; Ajo-Franklin, J.; Mukhopadhyay, A.; Morgan, F.D. Hydrogeophysical Methods for Analyzing Aquifer Storage and Recovery Systems. Ground Water 2011, 49, 250-269. [CrossRef] [PubMed]

6. Händel, F.; Liu, G.; Dietrich, P.; Liedl, R.; Butler, J.J. Numerical assessment of ASR recharge using small-diameter wells and surface basins. J. Hydrol. 2014, 517, 54-63. [CrossRef]

7. Pyne, R.D.G. Aquifer Storage Recovery: A Guide to Groundwater Recharge through Wells; ASR Systems: Gainesville, FL, USA, 2005. 
8. Gale, I.N. Strategies for Managed Aquifer Recharge (MAR) in Semi-Arid Areas; United Nations Educational, Scientific and Cultural Organisation (UNESCO): Paris, France, 2005.

9. Dillon, P.J.; Pavelic, P.; Page, D.; Beringen, H.; Ward, J. Managed Aquifer Recharge: An Introduction; Waterlines Report Series No. 13; Australian Government, National Water Commission: Canberra, Australia, 2009.

10. Gale, I.N.; Neumann, I.; Calow, R.; Moench, M. The Effectiveness of Artificial Recharge of Groundwater: A Review; Commissioned Report CR/02/108N; British Geological Survey: Keyworth, UK, 2002.

11. Hannappel, S.; Scheibler, F.; Huber, A.; Sprenger, C. DEMEAU M.11.1 Characterization of European Managed Aquifer Recharge (MAR) Sites-Analysis. 2014, p. 141. Available online: http://demeau-fp7.eu/sites/ files/M11_1\%20catalogue\%20of\%20european\%20MAR\%20applications_plus_appendix.pdf (accessed on 2 December 2016).

12. Huber, A.; Scheibler, F. Development of a Catalogue on European MAR Sites—Documentation. 2013, p. 60. Available online: http://demeau-fp7.eu/system/files/results/d11.1\%20catalogue\%20of\%20European\% 20MAR\%20applications_0.pdf (accessed on 2 December 2016).

13. International Groundwater Resource Assessment Centre (IGRAC). Artificial Recharge of Groundwater in the World, Report. Available online: http://www.un-igrac.org/download/file/fid/769 (accessed on 2 December 2016).

14. O'Geen, A.T.; Saal, M.; Dahlke, H.; Doll, D.; Elkins, R.; Fulton, A.; Fogg, G.; Harter, T.; Hopmans, J.W.; Ingels, C.; et al. Soil suitability index identifies potential areas for groundwater banking on agricultural lands. Calif. Agric. 2015, 69, 75-84. [CrossRef]

15. Stefan, C.; Ansems, N. Web-GIS of Global Inventory of Managed Aquifer Recharge (MAR) Applications. Available online: http:/ / marportal.un-igrac.org (accessed on 2 December 2016).

16. Clark, J.F.; Hudson, G.B.; Davisson, M.L.; Woodside, G.; Herndon, R. Geochemical Imaging of Flow Near an Artificial Recharge Facility, Orange County, California. Ground Water 2004, 42, 167-174. [CrossRef] [PubMed]

17. Maliva, R.G.; Herrmann, R.; Coulibaly, K.; Guo, W. Advanced aquifer characterization for optimization of managed aquifer recharge. Environ. Earth Sci. 2015, 73, 7759-7767. [CrossRef]

18. Kloppmann, W.; Aharoni, A.; Chikurel, H.; Dillon, P.; Gaus, I.; Guttman, J.; Kaitzer, T.; Kremer, S.; Masciopinto, C.; Miotliński, K.; et al. Use of groundwater models for prediction and optimisation of the behaviour of MAR sites. In Water Reclamation Technologies for Safe Managed Aquifer Recharge; Kazner, C., Wintgens, T., Dillon, P., Eds.; International Water Association Publications: London, UK, 2012.

19. National Water Resource Management Ministerial Council (NRMMC); Environment Protection; Heritage Council (EPHC); National Health and Medical Research Council (NHMRC). Australian Guidelines for Water Recycling: Managed Aquifer Recharge; National Water Quality Management Strategy Document 24; NRMMC, EPHC, NHMRC: Canberra, Australia, 2009; p. 237.

20. Environmental and Water Resources Institute (EWRI). Standard Guidelines for Artificial Recharge of Ground Water; ASCE Standard; American Society of Civil Engineers: Reston, VA, USA, 2001.

21. Stefan, C. Global MAR Index-Worldwide Database for Managed Aquifer Recharge Applications. In $A Q U A$ 2015: Back to the FUTURE! 42nd International Congress of International Association of Hydrogeologists-Abstract Book; Ducci, D., Pettita, M., Eds.; Societa Geologica Italiana: Rome, Italy, 2016.

22. Glendenning, C.J.; Vervoort, R.W. Hydrological impacts of rainwater harvesting (RWH) in a case study catchment: The Arvari River, Rajasthan, India: Part 2. Catchment-scale impacts. Agric. Water Manag. 2011, 98, 715-730. [CrossRef]

23. Perrin, J.; Massuel, S.; Ahmed, S. Contribution of percolation tanks to total aquifer recharge: The example of Gajwel watershed, southern India. In Achieving Groundwater Supply Sustainability \& Reliability through Managed Aquifer Recharge, Proceedings of the 7th International Symposium on Managed Aquifer Recharge, ISMAR-7, Abu Dhabi, UAE, 9-13 October 2009; Draeger, M., Ed.; 2012; pp. 251-258. Available online: http:/ /www.dinamar.es/pdf/ismar7-proceedingsbook.pdf (accessed on 2 December 2016).

24. Darcy, H. Les Fontaines Publiques de la Ville de Dijon: Exposition et Application; Victor Dalmont: Paris, France, 1856. (In French)

25. Richards, L.A. Capillary conduction of liquids through porous mediums. Physics 1931, 1, 318-333. [CrossRef]

26. Merritt, M.L. Recovering Fresh Water Stored in Saline Limestone Aquifers. Ground Water 1986, 24, 516-529. [CrossRef]

27. Merritt, M.L. Subsurface Storage of Freshwater in South Florida: A Digital Model Analysis of Recoverability; Water Supply Paper 2261; U.S. Geological Survey: Alexandria, VA, USA, 1985. 
28. Holzbecher, E.; Grützmacher, G.; Amy, G.; Wiese, B.; Sharma, S.K. The Bank Filtration Simulator-A MATLAB GUI. In Environmental Informatics and Industrial Ecology, Proceedings of the 22nd International Conference on Informatics for Environmental Protection, Enviroinfo 2008, Lüneburg, Germany, 10-12 September 2008; Möller, A., Page, B., Schreiber, M., Eds.; Shaker: Aachen, Germany, 2008.

29. Stuyfzand, P.J.; Wakker, J.C.; Putters, B. Water quality changes during Aquifer Storage and Recovery (ASR): Results from pilot Herten (Netherlands), and their implications for modeling. In Recharge Systems for Protecting and Enhancing Groundwater Resources, Proceedings of the 5th International Symposium on Management of Aquifer Recharge, ISMAR5, Berlin, Germany, 11-16 June 2005; UNESCO: Paris, France, 2006; pp. 164-173.

30. Pérez-Patricio, A. Integrated Modeling of Clogging Processes in Artificial Groundwater Recharge. Ph.D. Thesis, Technical University of Catalonia, Barcelona, Spain, 2001.

31. Miller, R.; Correll, R. ASRRI: A predictive index of contaminant attenuation during aquifer storage and recovery. In Management of Aquifer Recharge for Sustainability, Proceedings of the 4th International Symposium on Artificial Recharge of Groundwater, ISAR-4, Adelaide, Australia, 22-26 September 2002; Dillon, P., Ed.; A.A. Balkema: Lisse, The Netherlands, 2002; pp. 69-74.

32. Ward, J.D.; Simmons, C.T.; Dillon, P.J.; Pavelic, P. Integrated assessment of lateral flow, density effects and dispersion in aquifer storage and recovery. J. Hydrol. 2009, 370, 83-99. [CrossRef]

33. McDonald, M.G.; Harbaugh, A.W. A Modular Three-Dimensional Finite-Difference Ground-Water Flow Model; Techniques of Water-Resources Investigations, Book 6, Chapter A1 (TWRI6-A1); U.S. Geological Survey: Washington, DC, USA, 1988.

34. Diersch, H.J.G.; Kolditz, O. Variable-density flow and transport in porous media: Approaches and challenges. Adv. Water Resour. 2002, 25, 899-944. [CrossRef]

35. Langevin, C.D.; Thorne, D.T.; Drausman, A.M.; Sukop, M.C.; Guo, W. SEAWAT Version 4: A Computer Program for Simulation of Multi-Species Solute and Heat Transport; Techniques and Methods Book 6, Chapter A22 (TM6A22); U.S. Geological Survey: Reston, VA, USA, 2008; p. 39.

36. Kenneth, L. Guide to the Revised Heat and Solute Transport Simulator: HST3D-Version 2; Water-Resources Investigations Report 97-4157; U.S. Geological Survey: Denver, CO, USA, 1997; p. 149.

37. Parkhust, D.L.; Kipp, K.L.; Engesgaard, P.; Charlton, S.R. PHAST-A Program for Simulating Ground-Water Flow, Solute Transport, and Multicomponent Geochemical Reactions; Techniques and Methods Book 6, Chapter A8 (TM6A8); U.S. Geological Survey: Denver, CO, USA, 2004; p. 154.

38. Thiéry, D. Software MARTHE, Modelling of Aquifers with a Rectangular Grid in Transient State for Hydrodynamic Calculations of Heads and Flows; Release 4.3; Report BRGM 4S/EAU in R32548; Bureau de Recherches Géologiques et Minières: Orléans, France, 1990; p. 201.

39. Šejna, M.; Šimunek, J.; Van Genuchten, M.T. The Hydrus Software Package for Simulating the Two- and Three-Dimensional Movement of Water, Heat and Multiple Solutes in Variably-Saturated Media. Hydrus User Manual; PCProgress: Prague, Czech, 2011.

40. Sahoo, G.B.; Ray, C.; De Carlo, E.H. Calibration and validation of a physically distributed hydrological model, MIKE SHE, to predict streamflow at high frequency in a flashy mountainous Hawaii stream. J. Hydrol. 2006, 327, 94-109. [CrossRef]

41. Zheng, C.; Wang, P.P. MT3DMS: A Modular Three-Dimensional Multispecies Model for Simulation of Advection, Dispersion and Chemical Reactions of Contaminants in Groundwater Systems, Documentation and User's Guide; Contract Report SERDP-99-1; U.S. Army Engineer Research and Development Center: Vicksburg, MS, USA, 1999.

42. Nützmann, G.; Holzbecher, E.; Strahl, G.; Wiese, B.; Licht, E.; Grützmacher, G. Visual CXTFIT-A user-friendly simulation tool for modelling one-dimensional transport, sorption and degradation processes during bank filtration. In Recharge Systems for Protecting and Enhancing Groundwater Resources, Proceedings of the 5th International Symposium on Management of Aquifer Recharge, ISMAR5, Berlin, Germany, 11-16 June 2005; UNESCO: Paris, France, 2006; pp. 409-414.

43. Parkhust, D.L.; Appelo, C.A.J. PHREEQC (Version 2)—A Computer Program for Speciation, Batch-Reaction, One- Dimensional Transport, and Inverse Geochemical Calculations; Water Resources Investigations Report 99-4259; U.S. Geological Survey: Denver, CO, USA, 1999.

44. Prommer, H.; Barry, D.A.; Zheng, C. MODFLOW/MT3DMS-Based Reactive Multicomponent Transport Modeling. Ground Water 2003, 41, 247-257. [CrossRef] [PubMed] 
45. Stuyfzand, P.J. Simple models for reactive transport of pollutants and main constituents during artificial recharge and bank filtration. In Artificial Recharge of Groundwater, Proceedings of the Third International Symposium on Artificial Recharge of Groundwater, TISAR 98, Amsterdam, The Netherlands, 21-25 September 1998; Peters, J.H., Ed.; A.A. Balkema: Rotterdam, The Netherlands, 1998; pp. 427-434.

46. Clark, R.; Gonzalez, D.; Dillon, P.; Charles, S.; Cresswell, D.; Naumann, B. Reliability of water supply from stormwater harvesting and managed aquifer recharge with a brackish aquifer in an urbanising catchment and changing climate. Environ. Model. Softw. 2015, 72, 117-125. [CrossRef]

47. Gupta, S.K.; Cole, C.R.; Kincaid, C.T.; Monti, A.M. Coupled Fluid, Energy, and Solute Transport (CFEST) Model: Formulation and User's Manual; Technical Report; Office of Nuclear Waste Isolation: Columbus, $\mathrm{OH}$, USA, 1987.

48. COMSOL Introduction to Comsol Multiphysics ${ }^{\circledR}$; COMSOL: Burlington, MA, USA, 2011.

49. Schlumberger Eclipse Reservoir Simulation Software; Technical Description Version 2011.2; Schlumberger Corporation: Houston, TX, USA, 2011.

50. Szylkarski, S. Hydraulic Modeling of lock and weir structures on the River Murray. In Proceedings of the 6th Conference on Hydraulics in Civil Engineering: The State of Hydraulics, Hobart, Tasmania, 28-30 November 2002.

51. Oude Essink, G.P. MOC3D adapted to simulate 3D density-dependent groundwater flow. In Proceedings of the MODFLOW'98 Conference, Golden, CO, USA, 4-8 October 1998; pp. 291-303.

52. Voss, C.I. SUTRA, Saturated-Unsaturated TRAnsport: A Finite-Element Simulation Model for Saturated-Unsaturated Fluid-Density-Dependent Groundwater Flow with Energy Transport or Chemically Reactive Single-Species Solute Transport; Water Resources Investigations Report 84-4369; U.S. Geological Survey: Reston, VA, USA, 1984; p. 409.

53. Reeves, M.; Ward, D.; Johns, N.; Cranwell, R. Theory and implementation for SWIFT II. The Sandia Waste-Isolation Flow and Transport Model for Fractured Media; Release 4. 84; Sandia National Labs: Albuquerque, NM, USA, 1986.

54. Pruess, K.; Oldenburg, C.; Moridis, G. TOUGH2 User's Guide Version 2.0; Earth Sciences Division, Lawrence Berkeley National Laboratory University of California: Berkeley, CA, USA, 2012.

55. Valley, S.; Landini, F.; Pranzini, G.; Puppini, U.; Scardazzi, M.E.; Streetly, M.J. Transient flow modelling of an overexploited aquifer and simulation of artificial recharge measures. In Recharge Systems for Protecting and Enhancing Groundwater Resources, Proceedings of the 5th International Symposium on Management of Aquifer Recharge, ISMAR5, Berlin, Germany, 11-16 June 2005; UNESCO: Paris, France, 2006; pp. 435-442.

56. Jha, M.K.; Pfeiffer, O. Simulation modeling of salient artificial recharge techniques for sustainable groundwater management. In Recharge Systems for Protecting and Enhancing Groundwater Resources, Proceedings of the 5th International Symposium on Management of Aquifer Recharge, ISMAR5, Berlin, Germany, 11-16 June 2005; UNESCO: Paris, France, 2006; pp. 388-394.

57. De la Orden-Gómez, J.A.; Murillo, K.A. Recharge enhancement to precent saltwater intrusion in coastal Spain. In Management of Aquifer Recharge for Sustainability, Proceedings of the 4th International Symposium on Artificial Recharge of Groundwater, ISAR-4, Adelaide, Australia, 22-26 September 2002; Dillon, P., Ed.; A.A. Balkema: Lisse, The Netherlands, 2002; pp. 353-356.

58. Masciopinto, C. Management of aquifer recharge in Lebanon by removing seawater intrusion from coastal aquifers. J. Environ. Manag. 2013, 130, 306-312. [CrossRef] [PubMed]

59. Missimer, T.M.; Guo, W.; Maliva, R.G.; Rosas, J.; Jadoon, K.Z. Enhancement of wadi recharge using dams coupled with aquifer storage and recovery wells. Environ. Earth Sci. 2015, 73, 7723-7731. [CrossRef]

60. Virtue, D. Aquifer Storage and Recovery (ASR) Environmental Effects Report (EER) Supplement; Glenorchy City Council: Glenorchy, Australia, 2013.

61. Niazi, A.; Prasher, S.; Adamowski, J.; Gleeson, T. A System Dynamics Model to Conserve Arid Region Water Resources through Aquifer Storage and Recovery in Conjunction with a Dam. Water 2014, 6, 2300-2321. [CrossRef]

62. Eberlein, R.L.; Peterson, D.W. Understanding models with Vensim ${ }^{\mathrm{TM}}$. Eur. J. Oper. Res. 1992, 59, $216-219$. [CrossRef] 
63. Pavelic, P.; Dillon, P.J.; Robinson, N. Modelling of well-field design and operation for an Aquifer Storage Transfer and Recovery (ASTR) trial. In Recharge Systems for Protecting and Enhancing Groundwater Resources, Proceedings of the 5th International Symposium on Management of Aquifer Recharge, ISMAR5, Berlin, Germany, 11-16 June 2005; UNESCO: Paris, France, 2006; pp. 133-138.

64. Pavelic, P.; Dillon, P.J.; Robinson, N. Groundwater Modelling to Assist Well-Field Design and Operation for the ASTR Trial at Salisbury, South Australia; Technical Report No. 27/04; CSIRO Land and Water: Adelaide, Australia, 2004.

65. Ebrahim, G.Y. Modelling Groundwater Systems Understanding and Improving Groundwater Quantity and Quality Management. Ph.D. Thesis, UNESCO-IHE, Delft, The Netherlands, 2013.

66. Herrmann, R. ASR well field optimization in unconfined aquifers in the Middle East. In Recharge Systems for Protecting and Enhancing Groundwater Resources, Proceedings of the 5th International Symposium on Management of Aquifer Recharge, ISMAR5, Berlin, Germany, 11-16 June 2005; UNESCO: Paris, France, 2006; pp. 109-114.

67. Mosch, M.J.M. Dynamic simulation model for water management of large-scale artificial recharge system. In Artificial Recharge of Groundwater, Proceedings of the Third International Symposium on Artificial Recharge of Groundwater, TISAR 98, Amsterdam, The Netherlands, 21-25 September 1998; Peters, J.H., Ed.; A.A. Balkema: Rotterdam, The Netherlands, 1998; pp. 15-20.

68. Phillips, S.P.; Carlson, C.S.; Metzger, L.F.; Sneed, M.; Galloway, D.I.; Hudnut, K.W.; Ikehara, M.E. Optimal management of an ASR program to control land subsidence in Lancaster, California. In Management of Aquifer Recharge for Sustainability, Proceedings of the 4th International Symposium on Artificial Recharge of Groundwater, ISAR-4, Adelaide, Australia, 22-26 September 2002; Dillon, P., Ed.; A.A. Balkema: Lisse, The Netherlands, 2002; pp. 361-366.

69. Gómez Gómez, J.D.; Murillo Diaz, J.M.; López Geta, J.A.; Rodriguez Hermández, L. Analysis of feasibility and effects of artificial recharge in some aquifers. Modelling of integrated management in the Medio Vinalopó basin (Alicante, Spain). In Recharge Systems for Protecting and Enhancing Groundwater Resources, Proceedings of the 5th International Symposium on Management of Aquifer Recharge, ISMAR5, Berlin, Germany, 11-16 June 2005; UNESCO: Paris, France, 2006; pp. 807-812.

70. Landini, F.; Pranzini, G.; Scardazzi, M.E. Evaluation of the strategies for the re-equilibrium of the groundwater balance of an overexploited aquifer (Prato, Italy). In Recharge Systems for Protecting and Enhancing Groundwater Resources, Proceedings of the 5th International Symposium on Management of Aquifer Recharge, ISMAR5, Berlin, Germany, 11-16 June 2005; UNESCO: Paris, France, 2006; pp. 714-719.

71. Legg, C.; Sagstad, S. Optimization and use of various recharge techniques for reclaimed wastewater at a sensitive site in Glendale, Arizona. In Management of Aquifer Recharge for Sustainability, Proceedings of the 4th International Symposium on Artificial Recharge of Groundwater, ISAR-4, Adelaide, Australia, 22-26 September 2002; Dillon, P., Ed.; A.A. Balkema: Lisse, The Netherlands, 2002; pp. 333-338.

72. Martin, R.; Barnett, B.; Pitman, C.; Kaufmann, C.; Swiatnik, A.; Burgess, C. Modelling the regional impacts of multiple MAR schemes on the Northern Adelaide Plains. In Achieving Groundwater Supply Sustainability $\mathcal{E}$ Reliability through Managed Aquifer Recharge, Proceedings of the 7th International Symposium on Managed Aquifer Recharge, ISMAR7, Abu Dhabi, UAE, 9-13 October 2009; Draeger, M., Ed.; 2012; pp. 389-397. Available online: http:/ / www.dina-mar.es/pdf/ismar7-proceedingsbook.pdf (accessed on 2 December 2016).

73. Moorman, J.H.N.; Colin, M.G.; Stuyfzand, P.J. Iron precipitation clogging of recovery well following nearby deep well injection. In Management of Aquifer Recharge for Sustainability, Proceedings of the 4th International Symposium on Artificial Recharge of Groundwater, ISAR-4, Adelaide, Australia, 22-26 September 2002; Dillon, P., Ed.; A.A. Balkema: Lisse, The Netherlands, 2002; pp. 209-214.

74. Sheng, Z. An aquifer storage and recovery system with reclaimed wastewater to preserve native groundwater resources in El Paso, Texas. J. Environ. Manag. 2005, 75, 367-377. [CrossRef] [PubMed]

75. Banton, D.; Klisch, M. Aquifer Storage and Recovery in a Compartmentalized Basalt Aquifer System, Walla Walla, Washington. In Management of Aquifer Recharge for Sustainability, Proceedings of the 6th International Symposium on Managed Artificial Recharge of Groundwater, ISMAR6, Phoenix, AZ, USA, 28 October-2 November 2007; Fox, P., Ed.; Acacia Publishing: Phoenix, AZ, USA, 2007; pp. 307-320.

76. Holländer, H.M.; Mull, R.; Panda, S.N. A concept for managed aquifer recharge using ASR-wells for sustainable use of groundwater resources in an alluvial coastal aquifer in Eastern India. Phys. Chem. Earth $A / B / C$ 2009, 34, 270-278. [CrossRef] 
77. Holländer, H.M.; Mull, R.; Panda, S.N. A concept of managed aquifer recharge using ASR-wells for sustainable use of groundwater resources in an alluvial coastal aquifer in eastern India. In Management of Aquifer Recharge for Sustainability, Proceedings of the 6th International Symposium on Managed Artificial Recharge of Groundwater, ISMAR6, Phoenix, AZ, USA, 28 October-2 November 2007; Fox, P., Ed.; Acacia Publishing: Phoenix, AZ, USA, 2007; pp. 15-29.

78. Brown, C.J.; Nevulis, R. A model study of the proposed Everglades Restoration Hillsboro ASR Pilot Project. In Recharge Systems for Protecting and Enhancing Groundwater Resources, Proceedings of the 5th International Symposium on Management of Aquifer Recharge, ISMAR5, Berlin, Germany, 11-16 June 2005; UNESCO: Paris, France, 2006; pp. 73-78.

79. Hutchinson, A.S. The San Gabriel Valley Recycled Water Demonstration Project. In Artificial Recharge of Groundwater, Proceedings of the Third International Symposium on Artificial Recharge of Groundwater, TISAR 98, Amsterdam, The Netherlands, 21-25 September 1998; Peters, J.H., Ed.; A.A. Balkema: Rotterdam, The Netherlands, 1998; pp. 81-86.

80. Brown, C.J. A Stochastic Evaluation of the Subsidence Potential of the Hawthorn Group in South Florida as a Result of the CERP ASR System. In Management of Aquifer Recharge for Sustainability, Proceedings of the 6th International Symposium on Managed Artificial Recharge of Groundwater, ISMAR6, Phoenix, AZ, USA, 28 October-2 November 2007; Fox, P., Ed.; Acacia Publishing Incorporated: Phoenix, AZ, USA, 2007; pp. 590-600.

81. Misut, P.E.; Voss, C.I. Freshwater-saltwater transition zone movement during aquifer storage and recovery cycles in Brooklyn and Queens, New York City, USA. J. Hydrol. 2007, 337, 87-103. [CrossRef]

82. Rowland, F. Increase in Abstraction and Reinjection at the Cloudbreak Mine; Environmental Protection Authority: Mount Gambier, Australia, 2015; p. 131.

83. Van Ginkel, M.; Olsthoorn, T.N.; Smidt, E.; Darwish, R.; Rashwan, S. Fresh Storage Salines Extraction (FSSE) wells, feasibility of freshwater storage in saline aquifer with a focus on the Red Sea coast, Egypt. In Achieving Groundwater Supply Sustainability \& Reliability through Managed Aquifer Recharge, Proceedings of the 7th International Symposium on Managed Aquifer Recharge, ISMAR7, Abu Dhabi, UAE, 9-13 October 2009; Draeger, M., Ed.; 2012; pp. 336-349. Available online: http://www.dina-mar.es/pdf/ismar7proceedingsbook.pdf (accessed on 2 December 2016).

84. Brown, C.J. Planning Decision Framework for Brackish Water Aquifer, Storage and Recovery (ASR) Projects. Ph.D. Thesis, University of Florida, Gainesville, FL, USA, 2005.

85. Guo, W.; Maliva, R.G.; Missimer, T.M. Recovery Efficiency Assessment of an ASR Well Using Groundwater Models. In Achieving Groundwater Supply Sustainability \& Reliability through Managed Aquifer Recharge, Proceedings of the 7th International Symposium on Managed Aquifer Recharge, ISMAR7, Abu Dhabi, UAE, 9-13 October 2009; Draeger, M., Ed.; 2012; pp. 414-421. Available online: http:/ /www.dina-mar.es/pdf/ ismar7-proceedingsbook.pdf (accessed on 2 December 2016).

86. Lowry, C.S.; Anderson, M.P. An Assessment of Aquifer Storage Recovery Using Ground Water Flow Models. Ground Water 2006, 44, 661-667. [CrossRef] [PubMed]

87. Quinones-Aponte, V.; Wexler, E.J. Preliminary Assessment of Injection, Storage, and Recovery of Freshwater in the Lower Hawthorn Aquifer, Cape Coral, Florida; Water Resources Investigations Report 94-4121; U.S. Geological Survey: Tallahassee, FL, USA, 1995.

88. Streetly, M.J. The use of modelling to predict the behaviour of ASR systems. In Artificial Recharge of Groundwater, Proceedings of the Third International Symposium on Artificial Recharge of Groundwater, TISAR 98, Amsterdam, The Netherlands, 21-25 September 1998; Peters, J.H., Ed.; A.A. Balkema: Rotterdam, The Netherlands, 1998; pp. 263-267.

89. Yobbi, D.K. Simulation of Subsurface Storage and Recovery of Effluent Using Multiple Wells, St. Petersburg, Florida; WRIR 97-4024; Water Resources Investigations Report 97-4024; U.S. Geological Survey: Tallahassee, FL, USA, 1997.

90. Yobbi, D.K. Simulation of Subsurface Storage and Recovery of Treated Effluent Injected in a Saline Aquifer, St. Petersburg, Florida; WRIR 95-4271; Water Resources Investigations Report 95-4271; U.S. Geological Survey: Tallahassee, FL, USA, 1996. 
91. Pavelic, P.; Dillon, P.J. Lumped parameter estimation of initial recovery efficiency during aquifer storage and recovery. In Management of Aquifer Recharge for Sustainability, Proceedings of the 4th International Symposium on Artificial Recharge of Groundwater, ISAR-4, Adelaide, Australia, 22-26 September 2002; A.A. Balkema: Lisse, The Netherlands, 2002; pp. 285-290.

92. Vacher, H.L.; Hutchings, W.C.; Budd, D.A. Metaphors and Models: The ASR Bubble in the Floridan Aquifer. Ground Water 2006, 44, 144-154. [CrossRef] [PubMed]

93. Guo, W.; Coulibaly, K.; Maliva, R.G. Simulated effects of aquifer heterogeneity on ASR system performance. Environ. Earth Sci. 2015, 73, 7803-7809. [CrossRef]

94. Levannier, A. Modeling of wellbore effects in Managed Aquifer Recharge monitoring. In Achieving Groundwater Supply Sustainability \& Reliability through Managed Aquifer Recharge, Proceedings of the 7th International Symposium on Managed Aquifer Recharge, ISMAR7, Abu Dhabi, UAE, 9-13 October 2009; Draeger, M., Ed.; 2012; pp. 85-92. Available online: http://www.dina-mar.es/pdf/ismar7-proceedingsbook. pdf (accessed on 2 December 2016).

95. Ward, J.D.; Simmons, C.T.; Dillon, P.J. Variable-density modelling of multiple-cycle aquifer storage and recovery (ASR): Importance of anisotropy and layered heterogeneity in brackish aquifers. J. Hydrol. 2008, 356, 93-105. [CrossRef]

96. Miotliński, K.; Dillon, P.J.; Pavelic, P.; Barry, K.; Kremer, S. Recovery of Injected Freshwater from a Brackish Aquifer with a Multiwell System. Groundwater 2014, 52, 495-502. [CrossRef] [PubMed]

97. Zuurbier, K.G.; Kooiman, J.W.; Groen, M.M.A.; Maas, B.; Stuyfzand, P.J. Enabling Successful Aquifer Storage and Recovery of Freshwater Using Horizontal Directional Drilled Wells in Coastal Aquifers. J. Hydrol. Eng. 2015, 20. [CrossRef]

98. Zuurbier, K.G.; Zaadnoordijk, W.J.; Stuyfzand, P.J. How multiple partially penetrating wells improve the freshwater recovery of coastal aquifer storage and recovery (ASR) systems: A field and modeling study. J. Hydrol. 2014, 509, 430-441. [CrossRef]

99. Ward, J.D.; Simmons, C.T.; Dillon, P.J. A theoretical analysis of mixed convection in aquifer storage and recovery: How important are density effects? J. Hydrol. 2007, 343, 169-186. [CrossRef]

100. Brun, A.; Christensen, F.D.; Chrsitiansen, J.S.; Stuyfzand, P.J.; Timmer, H. Water quality modelling at the Langerak deep-well recharge site. In Artificial Recharge of Groundwater, Proceedings of the Third International Symposium on Artificial Recharge of Groundwater, TISAR 98, Amsterdam, The Netherlands, 21-25 September 1998; Peters, J.H., Ed.; A.A. Balkema: Rotterdam, The Netherlands, 1998; pp. 305-310.

101. Page, D.; Vanderzalm, J.; Barry, K.; Levett, K.; Kremer, S.; Ayuso-Gabella, M.N.; Dillon, P.; Toze, S.; Sidhu, J.; Shackleton, M.; et al. Operational Residual Risk Assessment for the Salisbury Stormwater ASTR Project; CSIRO Water for a Healthy Country National Research Flagship Report; CSIRO: Perth, Australia, 2009.

102. Petkewich, M.D.; Parkhurst, D.L.; Conlon, K.J.; Campbell, B.G.; Mirecki, J.E. Hydrologic and Geochemical Evaluation of Aquifer Storage Recovery in the Santee Limestone/Black Mingo Aquifer, Charleston, South Carolina, 1998-2002; Scientific Investigations Report (SIR 2004-5046); U.S. Geological Survey: Reston, VA, USA, 2004.

103. Prommer, H.; Descourvieres, C.D.; Handyside, M.; Hohnston, K.; Harris, B.; Li, Q.; Phang, H.; Costello, P.; Seibert, S.; Martin, M. Final Report-Aquifer Storage and Recovery of Potable Water in the Leederville Aquifer; CSIRO Water for a Healthy Country National Research Flagship Report; CSIRO: Perth, Australia, 2013; p. 86.

104. Prommer, H.; Stuyfzand, P.J. On the use of reactive multicomponent transport modelling for assessing water quality changes during managed aquifer recharge. In Recharge Systems for Protecting and Enhancing Groundwater Resources, Proceedings of the 5th International Symposium on Management of Aquifer Recharge, ISMAR5, Berlin, Germany, 11-16 June 2005; UNESCO: Paris, France, 2006; pp. 415-420.

105. Saaltink, M.W.; Ayora, C.; Stuyfzand, P.J.; Timmer, H. Modelling the effects of deep artificial recharge on groundwater quality. In Artificial recharge of groundwater, Proceedings of the Third International Symposium on Artificial Recharge of Groundwater, TISAR 98, Amsterdam, The Netherlands, 21-25 September 1998; Peters, J.H., Ed.; A.A. Balkema: Rotterdam, The Netherlands, 1998; pp. 423-425.

106. Stuyfzand, P.J.; Pyne, R.D.G. Arsenic behavior in SW Florida ASR systems and its expert modeling. In Achieving Groundwater Supply Sustainability \& Reliability through Managed Aquifer Recharge, Proceedings of the 7th International Symposium on Managed Aquifer Recharge, ISMAR7, Abu Dhabi, UAE, 9-13 October 2009; Draeger, M., Ed.; 2012; pp. 178-187. Available online: http://www.dina-mar.es/pdf/ismar7proceedingsbook.pdf (accessed on 2 December 2016). 
107. Wallis, I.; Prommer, H.; Simmons, C.T.; Post, V.; Stuyfzand, P.J. Numerical evaluation of arsenic behaviour during deep well injection. In Achieving Groundwater Supply Sustainability E Reliability through Managed Aquifer Recharge, Proceedings of the 7th International Symposium on Managed Aquifer Recharge, ISMAR7, Abu Dhabi, UAE, 9-13 October 2009; Draeger, M., Ed.; 2012; pp. 156-161. Available online: http:/ /www.dina-mar.es/pdf/ ismar7-proceedingsbook.pdf (accessed on 2 December 2016).

108. Wallis, I.; Prommer, H.; Pichler, T.; Post, V.; Norton, S.B.; Annable, M.D.; Simmons, C.T. Process-Based Reactive Transport Model To Quantify Arsenic Mobility during Aquifer Storage and Recovery of Potable Water. Environ. Sci. Technol. 2011, 45, 6924-6931. [CrossRef] [PubMed]

109. Wallis, I.; Prommer, H.; Simmons, C.T.; Post, V.; Stuyfzand, P.J. Evaluation of Conceptual and Numerical Models for Arsenic Mobilization and Attenuation during Managed Aquifer Recharge. Environ. Sci. Technol. 2010, 44, 5035-5041. [CrossRef] [PubMed]

110. Mirecki, J.E. Geochemical Models of Water-Quality Changes during Aquifer Storage Recovery (ASR) Cycle Tests, Phase 1: Geochemical Models Using Existing Data; TR-06-8; U.S. Army Corps of Engineers, Engineers Research and Development Center: Vicksburg, MS, USA, 2006.

111. Mirecki, J.E. Arsenic mobilization and sequestration during successive aquifer storage recovery (ASR) cycle tests in the carbonate Upper Floridan aquifer, South Florida. In Recharge Systems for Protecting and Enhancing Groundwater Resources, Proceedings of the 5th International Symposium on Management of Aquifer Recharge, ISMAR5, Berlin, Germany, 11-16 June 2005; UNESCO: Paris, France, 2006; pp. 304-310.

112. Descourvieres, C.; Prommer, H.; Hartog, N.; Oldham, C.; Greskowiak, J.; Patterson, B. Identification of Geochemical Controls on Sediment Reactivity and Buffering Processes During Managed Aquifer Recharge in a Heterogeneous Aquifer: Laboratory Experiments and Inverse Kinetic Reaction Modelling. In Achieving Groundwater Supply Sustainability \& Reliability through Managed Aquifer Recharge, Proceedings of the 7th International Symposium on Managed Aquifer Recharge, ISMAR7, Abu Dhabi, UAE, 9-13 October 2009; Draeger, M., Ed.; 2012; pp. 148-155. Available online: http://www.dina-mar.es/pdf/ismar7proceedingsbook.pdf (accessed on 2 December 2016).

113. Zhang, W.; Huan, Y.; Yu, X.; Liu, D.; Zhou, J. Multi-component transport and transformation in deep confined aquifer during groundwater artificial recharge. J. Environ. Manag. 2015, 152, 109-119. [CrossRef] [PubMed]

114. Antoniou, E.A.; Stuyfzand, P.J.; van Breukelen, B.M. Reactive transport modeling of an aquifer storage and recovery (ASR) pilot to assess long-term water quality improvements and potential solutions. Appl. Geochem. 2013, 35, 173-186. [CrossRef]

115. Antoniou, E.A.; van Breukelen, B.M.; Putters, B.; Stuyfzand, P.J. Hydrogeochemical patterns, processes and mass transfers during aquifer storage and recovery (ASR) in an anoxic sandy aquifer. Appl. Geochem. 2012, 27, 2435-2452. [CrossRef]

116. Gaus, I.; Shand, P.; Gale, I.N.; Williams, A.T.; Eastwood, J.C. Geochemical modelling of fluoride concentration changes during Aquifer Storage and Recovery (ASR) in the Chalk aquifer in Wessex, England. Q. J. Eng. Geol. Hydrogeol. 2002, 35, 203-208. [CrossRef]

117. Anderson, M.; Dewhurst, R.; Jones, M.; Baxter, K. Characterisation of turbidity and well clogging processes in a double porosity Chalk aquifer during the South London Artificial Recharge Scheme trials. In Recharge Systems for Protecting and Enhancing Groundwater Resources, Proceedings of the 5th International Symposium on Management of Aquifer Recharge, ISMAR 5, Berlin, Germany, 11-16 June 2005; UNESCO: Paris, France, 2006; pp. 593-598.

118. Page, D.; Vanderzalm, J.; Miotliński, K.; Barry, K.; Dillon, P.; Lawrie, K.; Brodie, R.S. Determining treatment requirements for turbid river water to avoid clogging of aquifer storage and recovery wells in siliceous alluvium. Water Res. 2014, 66, 99-110. [CrossRef] [PubMed]

119. Stuyfzand, P.J.; Wilem Kooiman, J.; Oosterhof, A.; Raat, K.J. Problems and solutions when recharging brackish aquifers with membrane concentrate from a less brackish groundwater source. In Management of Aquifer Recharge for Sustainability, Proceedings of the 6th International Symposium on Managed Artificial Recharge of Groundwater, ISMAR6, Phoenix, AZ, USA, 28 October-2 November 2007; Fox, P., Ed.; Acacia Publishing: Phoenix, AZ, USA, 2007; pp. 47-60.

120. Willis-Jones, B.; Brandes de Roos, I. Application of Large Scale Managed Aquifer Recharge in Mine Water Management, Cloudbreak Mine, Western Australia. In Clogging Issues Associated with Managed Aquifer Recharge Methods; Martin, R., Ed.; International Association of Hydrogeologists: Reading, UK, 2013; pp. 156-162. 
121. Youngs, J.; Willis-Jones, B.; Greenhalgh, D.; Mcphee, A.; Brown, D. Cloudbreak: The critical role of MAR in a major Pilbara mine water management scheme. In Achieving Groundwater Supply Sustainability E Reliability through Managed Aquifer Recharge, Proceedings of the 7th International Symposium on Managed Aquifer Recharge, ISMAR7, Abu Dhabi, UAE, 9-13 October 2009; Draeger, M., Ed.; 2012; pp. 538-545. Available online: http:/ / www.dina-mar.es/pdf/ismar7-proceedingsbook.pdf (accessed on 2 December 2016).

122. Gutiérrez-Ojeda, C.; Martínez-Morales, M.; Ortiz-Flores, G. Artificial recharge of groundwater in a coal mining area of northeast Mexico. In Management of Aquifer Recharge for Sustainability, Proceedings of the 6th International Symposium on Managed Artificial Recharge of Groundwater, ISMAR6, Phoenix, AZ, USA, 28 October-2 November 2007; Fox, P., Ed.; Acacia Publishing Incorporated: Gilbert, AZ, USA, 2007; pp. 74-83.

123. Vanderzalm, J.; Smitt, C.; Barry, K.; Dillon, P.; Davidge, S.; Gornall, D.; Seear, H.; Ife, D. Potential for Injection Well Clogging in an Anoxic Sandstone Aquifer Receiving Gresh, Deoxygenated but Chlorinated Injectant. In Clogging Issues Associated with Managed Aquifer Recharge Methods; Martin, R., Ed.; International Association of Hydrogeologists: Reading, UK, 2013; pp. 34-49.

124. Pérez-Patricio, A.; Carrera, J. A conceptual and numerical model to characterize clogging. In Artificial Recharge of Groundwater, Proceedings of the Third International Symposium on Artificial Recharge of Groundwater, TISAR 98, Amsterdam, The Netherlands, 21-25 September 1998; Peters, J.H., Ed.; A.A. Balkema: Rotterdam, The Netherlands, 1998; pp. 55-60.

125. Dillon, P.; Vanderzalm, J.; Page, D.; Barry, K.; Gonzalez, D.; Muthukaruppan, M.; Hudson, M. Analysis of ASR Clogging Investigations at Three Australian ASR Sites in a Bayesian Context. Water 2016, 8, 442. [CrossRef]

126. Dillon, P.J.; Toze, S.; Pavelic, P.; Vanderzalm, J.L.; Barry, K.; Ying, G.-G.; Kookana, R.; Skjemstad, J.; Nicholson, B.; Miller, R.; et al. Water quality improvements during aquifer storage and recovery at ten sites. In Recharge Systems for Protecting and Enhancing Groundwater Resources, Proceedings of the 5th International Symposium on Management of Aquifer Recharge, ISMAR5, Berlin, Germany, 11-16 June 2005; UNESCO: Paris, France, 2006; pp. 85-94.

127. Page, D.; Barry, K.; Chassagne, A.; Pavelic, P.; Dillon, P.; Purdie, M.; Pittman, C.; Rinck-Pfeiffer, S.; Regel, R. Application of the Hazard Analysis and Critical Control Point (HACCP) risk management framework to managed aquifer recharge. In Management of Aquifer Recharge for Sustainability, Proceedings of the 6th International Symposium on Managed Artificial Recharge of Groundwater, ISMAR6, Phoenix, AZ, USA, 28 October-2 November 2007; Fox, P., Ed.; Acacia Publishing: Phoenix, AZ, USA, 2007; pp. 578-589.

128. Vanderzalm, J.L.; Dillon, P.; Marvanek, S.; Page, D. Over 100 years of drinking stormwater treated through MAR: Assessing the risks of stormwater recharge on the quality of Blue Lake. In Management of Aquifer Recharge for Sustainability, Proceedings of the 6th International Symposium on Managed Artificial Recharge of Groundwater, ISMAR6, Phoenix, AZ, USA, 28 October-2 November 2007; Fox, P., Ed.; Acacia Publishing: Phoenix, AZ, USA, 2007; pp. 616-625.

129. Page, D.; Gonzalez, D.; Torkzaban, S.; Toze, S.; Sidhu, J.; Miotliński, K.; Barry, K.; Dillon, P. Microbiological risks of recycling urban stormwater via aquifers for various uses in Adelaide, Australia. Environ. Earth Sci. 2015, 73, 7733-7737. [CrossRef]

130. Masciopinto, C.; La Mantia, R.; Chrysikopoulos, C.V. Fate and transport of pathogens in a fractured aquifer in the Salento area, Italy. Water Resour. Res. 2008, 44, W01404. [CrossRef]

131. Greskowiak, J.; Prommer, H.; Massmann, G.; Nützmann, G. Modeling Seasonal Redox Dynamics and the Corresponding Fate of the Pharmaceutical Residue Phenazone During Artificial Recharge of Groundwater. Environ. Sci. Technol. 2006, 40, 6615-6621. [CrossRef] [PubMed]

132. Greskowiak, J.; Prommer, H.; Vanderzalm, J.; Pavelic, P.; Dillon, P. Modeling of carbon cycling and biogeochemical changes during injection and recovery of reclaimed water at Bolivar, South Australia: Modeling Carbon Cycling. Water Resour. Res. 2005, 41, W10418. [CrossRef]

133. Vanderzalm, J.L.; Page, D.W.; Barry, K.E.; Dillon, P.J. Application of a probabilistic modelling approach for evaluation of nitrogen, phosphorus and organic carbon removal efficiency during four successive cycles of aquifer storage and recovery (ASR) in an anoxic carbonate aquifer. Water Res. 2013, 47, 2177-2189. [CrossRef] [PubMed] 
134. Gutiérrez-Ojeda, C.; Cardona, A.; Martínez-Morales, M.; Aparicio-Mijares, F. Geochemical evaluation of artificial recharge to intermediate flow systems in a carbonate aquifer from northeast Mexico. In Recharge Systems for Protecting and Enhancing Groundwater Resources, Proceedings of the 5th International Symposium on Management of Aquifer Recharge, ISMAR5, Berlin, Germany, 11-16 June 2005; UNESCO: Paris, France, 2006; pp. 274-279.

135. Dillon, P.J.; Pavelic, P.; Page, D.; Miotlinski, K.; Levett, K.; Barry, K.; Taylor, R.; Wakelin, S.; Vanderzalm, J.L.; Molloy, R.; et al. Developing Aquifer Storage and Recovery (ASR) Opportunities in Melbourne-Rossdale ASR Demonstration Project Final Report; CSIRO Water for a Healthy Country National Research Flagship Report; CSIRO: Perth, Australia, 2010.

136. Greskowiak, J.; Prommer, H.; Vanderzalm, J.; Pavelic, P.; Dillon, P.J. Quantifying biogeochemical changes during ASR of reclaimed water at Bolivar, South Australia. In Recharge Systems for Protecting and Enhancing Groundwater Resources, Proceedings of the 5th International Symposium on Management of Aquifer Recharge, ISMAR5, Berlin, Germany, 11-16 June 2005; UNESCO: Paris, France, 2006; pp. 360-365.

137. Wallbridge \& Gilbert. Urban Stormwater Harvesting Options Study. 2009. Available online: https://www.lga.sa.gov.au/ webdata/resources/files/Urban_Stormwater_Harvesting_Options_Study _-_Report.pdf (accessed on 2 December 2016).

138. Monninkhoff, L.; Kaden, S. Managed Aquifer Recharge through a penetrated river bed in Shandong, China. In Achieving Groundwater Supply Sustainability \& Reliability through Managed Aquifer Recharge, Proceedings of the 7th International Symposium on Managed Aquifer Recharge, ISMAR7, Abu Dhabi, UAE, 9-13 October 2009; Draeger, M., Ed.; 2012; pp. 267-274. Available online: http://www.dina-mar.es/pdf/ ismar7-proceedingsbook.pdf (accessed on 2 December 2016).

139. Stefan, C.; Fröhlich, T.; Fuchs, L.; Junghanns, R.; Phan, H.M.; Tran, V.N.; Werner, P. Sustainable water resources management in the Long Bien district of Hanoi, Vietnam. Water Sci. Technol. Water Supply 2012, 12, 737-746. [CrossRef]

140. Karimov, A.; Mavlonov, A.; Miryusupov, F.; Gracheva, I.; Borisov, V.; Abdurahmonov, B. Modelling policy alternatives toward managed aquifer recharge in the Fergana Valley, Central Asia. Water Int. 2012, 37, 380-394. [CrossRef]

141. Karimov, A.; Gracheva, I.; Miryusupov, F. Modeling the Managed Aquifer Recharge for Groundwater Salinity Management in the Sokh River Basin. In Achieving Groundwater Supply Sustainability E Reliability through Managed Aquifer Recharge, Proceedings of the 7th International Symposium on Managed Aquifer Recharge, ISMAR7, Abu Dhabi, UAE, 9-13 October 2009; Draeger, M., Ed.; 2012; pp. 203-211. Available online: http://www.dina-mar.es/pdf/ismar7-proceedingsbook.pdf (accessed on 2 December 2016).

142. Barber, M.E.; Hossain, A.; Covert, J.J.; Gregory, G.J. Augmentation of seasonal low stream flows by artificial recharge in the Spokane Valley-Rathdrum Prairie aquifer of Idaho and Washington, USA. Hydrogeol. J. 2009, 17, 1459-1470. [CrossRef]

143. Ebrahim, G.Y.; Jonoski, A.; Al-Maktoumi, A.; Ahmed, M.; Mynett, A. Simulation-Optimization Approach for Evaluating the Feasibility of Managed Aquifer Recharge in the Samail Lower Catchment, Oman. J. Water Resour. Plan. Manag. 2015, 142. [CrossRef]

144. Gaus, I.; Cikurel, H.; Aharoni, A.; Guttman, Y.; Azaroual, M.; Kloppmann, W. Alternative SAT of secondary effluents using a combination of UF and short term SAT for increasing infiltration rates at the Shafdan site (Israel). In Management of Aquifer Recharge for Sustainability, Proceedings of the 6th International Symposium on Managed Artificial Recharge of Groundwater, ISMAR6, Phoenix, AZ, USA, 28 October-2 November 2007; Fox, P., Ed.; Acacia Publishing Incorporated: Phoenix, AZ, USA, 2007; pp. 544-557.

145. Riches, J.; Batey, J.; Jones, M.; Butcher, A.S.; Newell, A.J.; Gale, I.N. Hydrogeochemistry of aquifer storage and recovery in the Lower Greensand (London, UK) for seasonal and drought public supply. In Management of Aquifer Recharge for Sustainability, Proceedings of the 6th International Symposium on Managed Artificial Recharge of Groundwater, ISMAR6, Phoenix, AZ, USA, 28 October-2 November 2007; Fox, P., Ed.; ISMAR Proceedings; Acacia Publishing Incorporated: Phoenix, AZ, USA, 2007; pp. 198-208.

146. Prommer, H.; Stuyfzand, P.J. Identification of Temperature-Dependent Water Quality Changes during a Deep Well Injection Experiment in a Pyritic Aquifer. Environ. Sci. Technol. 2005, 39, 2200-2209. [CrossRef] [PubMed]

147. Appelo, C.A.J.; Drijver, B.; Hekkenberg, R.; Jonge, M. Modeling In Situ Iron Removal from Ground Water. Ground Water 1999, 37, 811-817. [CrossRef] 
148. Griffioen, J.; Lorens, A.L.; Venema, P.; te Stroet, C.B.; Minnema, B.; Laeven, M.P.; Stuyfzand, P.J.; van Beek, C.G.E.M.; Beekman, W. An integrated model for predicting and assessing the development of groundwater quality. In Artificial Recharge of Groundwater, Proceedings of the Third International Symposium on Artificial Recharge of Groundwater, TISAR 98, Amsterdam, The Netherlands, 21-25 September 1998; Peters, J.H., Ed.; A.A. Balkema: Rotterdam, The Netherlands, 1998; pp. 419-421.

149. Parkhurst, D.L. Geochemical Modeling of an Aquifer Storage Recovery Experiment, Charleston, South Carolina. In Proceedings of the U.S. Geological Survey Artificial Recharge Workshop, Sacramento, CA, USA, 2-4 April 2002; pp. 38-41.

150. Majumdar, P.K.; Sekhar, M.; Sridharan, K.; Mishra, G.C. Numerical Simulation of Groundwater Flow with Gradually Increasing Heterogeneity due to Clogging. J. Irrig. Drain. Eng. 2008, 134, 400-404. [CrossRef]

151. Kohlfahl, C.; Harmann, E.; Pekdeger, A. Modelling of artificial water oscillations in a flooded lignite mine. In Management of Aquifer Recharge for Sustainability, Proceedings of the 4th International Symposium on Artificial Recharge of Groundwater, ISAR-4, Adelaide, Australia, 22-26 September 2002; Dillon, P., Ed.; A.A. Balkema: Lisse, The Netherlands, 2002; pp. 261-264.

152. Izbicki, J.A.; Petersen, C.E.; Glotzbach, K.J.; Metzger, L.F.; Christensen, A.H.; Smith, G.A.; O'Leary, D.; Fram, M.S.; Joseph, T.; Shannon, H. Aquifer Storage Recovery (ASR) of chlorinated municipal drinking water in a confined aquifer. Appl. Geochem. 2010, 25, 1133-1152. [CrossRef]

153. Brown, C.J.; Misut, P.E. Aquifer geochemistry at potential aquifer storage and recovery sites in coastal plain aquifers in the New York City area, USA. Appl. Geochem. 2010, 25, 1431-1452. [CrossRef]

154. Stefanescu, C.; Dassargues, A. Simulation of pumping and artificial recharge in a phreatic aquifer near Bucharest, Romania. Hydrogeol. J. 1996, 4, 72-83. [CrossRef]

155. Hutchinson, C.B. Simulation of Aquifer Storage Recovery of Excess Desalinated Seawater, Al Ain Area, Abu Dhabi Emirate; Open-File Report 98-410; U.S. Geological Survey: Alexandria, VA, USA, 1998.

156. Saharawat, Y.; Malik, R.; Jhorar, B.; Chaudhary, N.; Ingwersen, J.; Streck, T. Simulating effect of successive cycles in aquifer storage and recovery well in India. In Recharge Systems for Protecting and Enhancing Groundwater Resources, Proceedings of the 5th International Symposium on Management of Aquifer Recharge, ISMAR5, Berlin, Germany, 11-16 June 2005; UNESCO: Paris, France, 2006; pp. 421-427.

157. Goyal, V.; Jhorar, B.; Malik, R.; Streck, T. Simulation of groundwater recharge from an aquifer storage recovery well under shallow water-table condition. Curr. Sci. 2009, 96, 376-385.

158. Charlesworth, P.B.; Narayan, K.A.; Bristow, K.L.; Lowis, B.; Laidlow, G.; McGowan, R. The Burgekin Delta-Australia's oldest artificial recharge scheme. In Management of Aquifer Recharge for Sustainability, Proceedings of the 4th International Symposium on Artificial Recharge of Groundwater, ISAR-4, Adelaide, Australia, 22-26 September 2002; Dillon, P., Ed.; A.A. Balkema: Lisse, The Netherlands, 2002; pp. 347-352.

159. Kremer, S.; Pavelic, P.; Dillon, P.; Barry, K. Flow and Solute Transport Observations and Modelling from the First Phase of Flushing Operations at the Salisbury ASTR Site; CSIRO Water for a Healthy Country Flagship Report; CSIRO: Perth, Australia, 2008.

160. Kremer, S.; Barry, K.; Levett, K.; Miotliński, K.; Dillon, P. Revised Flow and Solute Transport Modelling for ASTR Operations, South Australia; CSIRO Water for a Healthy Country Flagship Report; CSIRO: Perth, Australia, 2010.

161. Sedighi, A.; Klammler, H.; Brown, C.; Hatfield, K. A semi-analytical model for predicting water quality from an aquifer storage and recovery system. J. Hydrol. 2006, 329, 403-412. [CrossRef]

162. Konikow, L.F.; August, L.L.; Voss, C.I. Effects of Clay Dispersion on Aquifer Storage and Recovery in Coastal Aquifers. Transp. Porous Media 2001, 43, 45-64. [CrossRef]

163. Lacher, L.; Turner, D.; Gungle, B.; Bushman, B.; Richter, H. Application of Hydrologic Tools and Monitoring to Support Managed Aquifer Recharge Decision Making in the Upper San Pedro River, Arizona, USA. Water 2014, 6, 3495-3527. [CrossRef]

164. Mirlas, V.; Antonenko, V.; Kulagin, V.; Kuldeeva, E. Assessing artificial groundwater recharge on irrigated land using the MODFLOW model. Earth Sci. Res. 2015, 4, 16-34. [CrossRef]

165. Rahman, M.A.; Rusteberg, B.; Gogu, R.C.; Lobo Ferreira, J.P.; Sauter, M. A new spatial multi-criteria decision support tool for site selection for implementation of managed aquifer recharge. J. Environ. Manag. 2012, 99, 61-75. [CrossRef] [PubMed] 
166. Rastogi, A.K.; Pandey, P.J. Influence of artificial recharge basin shapes on the mound underneath in phreatic aquifers. In Management of Aquifer Recharge for Sustainability, Proceedings of the 4th International Symposium on Artificial Recharge of Groundwater, ISAR-4, Adelaide, Australia, 22-26 September 2002; Dillon, P., Ed.; A.A. Balkema: Lisse, The Netherlands, 2002; pp. 295-297.

167. Smith, A.J.; Pollock, D.W. Assessment of Managed Aquifer Recharge Potential Using Ensembles of Local Models. Ground Water 2012, 50, 133-143. [CrossRef] [PubMed]

168. Rahman, M.A.; Rusteberg, B.; Uddin, M.S.; Lutz, A.; Saada, M.A.; Sauter, M. An integrated study of spatial multicriteria analysis and mathematical modelling for managed aquifer recharge site suitability mapping and site ranking at Northern Gaza coastal aquifer. J. Environ. Manag. 2013, 124, 25-39. [CrossRef] [PubMed]

169. Namjou, P.; Pattle, A.D. Hydrogeological feasibility of disposal of treated effluent in coastal dunes near Auckland, New Zealand. In Management of Aquifer Recharge for Sustainability, Proceedings of the 4th International Symposium on Artificial Recharge of Groundwater, ISAR-4, Adelaide, Australia, 22-26 September 2002; Dillon, P., Ed.; A.A. Balkema: Lisse, The Netherlands, 2002; pp. 273-277.

170. Evans, P.; Arunakumaren, J. Groundwater Management in Bribie Island for Urban Expansion. In Achieving Groundwater Supply Sustainability \& Reliability through Managed Aquifer Recharge, Proceedings of the 7th International Symposium on Managed Aquifer Recharge, ISMAR7, Abu Dhabi, UAE, 9-13 October 2009; Draeger, M., Ed.; 2012; pp. 381-388. Available online: http://www.dina-mar.es/pdf/ismar7proceedingsbook.pdf (accessed on 2 December 2016).

171. Pipe-Martin, C. Protecting an island aquifer by using recycled water as a hydraulic barrier-A case study of Bribie Island. In Recharge Systems for Protecting and Enhancing Groundwater Resources, Proceedings of the 5th International Symposium on Management of Aquifer Recharge, ISMAR5, Berlin, Germany, 11-16 June 2005; UNESCO: Paris, France, 2006; pp. 856-861.

172. Zeelie, S. OMDEL dam and recharge ponds to enhance recharge in the Namib Desert. In Management of Aquifer Recharge for Sustainability, Proceedings of the 4th International Symposium on Artificial Recharge of Groundwater, ISAR-4, Adelaide, Australia, 22-26 September 2002; Dillon, P., Ed.; A.A. Balkema: Lisse, The Netherlands, 2002; pp. 361-366.

173. Knapton, A.; Jolly, P.; Pavelic, P.; Dillon, P.; Barry, K.; Mucha, M.; Gates, W. Feasibility of a pilot 600ML/yr Soil Aquifer Treatment Plant at the Arid Zone Research Institute: A Report. Prepared by DIPE and CSIRO for the Power \& Water Corporation. Technical Report No. 29/2004, 2004. Available online: http://www. territorystories.nt.gov.au/bitstream/10070/228889/1/WRA04029.pdf (accessed on 2 December 2016).

174. Abbo, H.; Gev, I. Numerical model as a predictive analysis tool for rehabilitation and conservation of the Israeli Coastal Aquifer: Example of the SHAFDAN Sewage Reclamation project. Desalination 2008, 226, 47-55. [CrossRef]

175. Kupfersberger, H. Managed aquifer recharge in Austria as central element of integrated water resources management. In Achieving Groundwater Supply Sustainability E Reliability through Managed Aquifer Recharge, Proceedings of the 7th International Symposium on Managed Aquifer Recharge, ISMAR7, Abu Dhabi, UAE, 9-13 October 2009; Draeger, M., Ed.; 2012; pp. 243-250. Available online: http://www.dina-mar.es/pdf/ ismar7-proceedingsbook.pdf (accessed on 2 December 2016).

176. Rahman, M.A. Decision Support for Managed Aquifer Recharge (MAR) Project Planning to Mitigate Water Scarcity Based on Non-Conventional Water Resources. Ph.D. Thesis, Georg-August-Universität zu Göttingen, Göttingen, Germany, 2011.

177. Yin, H.; Xu, Z.; Li, H.; Li, S. Numerical modeling of wastewater transport and degradation in soil aquifer. J. Hydrodyn. Ser. B 2006, 18, 597-605. [CrossRef]

178. Park, H.; Cha, D.-H.; Fox, P. Uncertainty Analysis of Mound Monitoring for Recharged Water from Surface Spreading Basins. J. Environ. Eng. 2006, 132, 1572-1579. [CrossRef]

179. Fox, P.; Park, H.; Cha, D.-H. Uncertainty Analysis of Mound Monitoring For Recharged Water from Surface Spreading Basins. In Management of Aquifer Recharge for Sustainability, Proceedings of the 6th International Symposium on Managed Artificial Recharge of Groundwater, ISMAR6, Phoenix, AZ, USA, 28 October-2 November 2007; Fox, P., Ed.; Acacia Publishing: Phoenix, AZ, USA, 2007; pp. 423-432.

180. Jorgensen, N.O.; Helleberg, B.B. Stable isotopes $(2 \mathrm{H}$ and $18 \mathrm{O})$ and chloride as environmental tracers in a study of artificial recharge in Denmark. In Management of Aquifer Recharge for Sustainability, Proceedings of the 4th International Symposium on Artificial Recharge of Groundwater, ISAR-4, Adelaide, Australia, 22-26 September 2002; Dillon, P., Ed.; A.A. Balkema: Lisse, The Netherlands, 2002; pp. 245-250. 
181. Ting, C.-S.; Lee, C.H.; Lin, C.Y.; Chen, S.H.; Chang, K.C. Infiltration mechanism of artificial recharge of groundwater-A case study at Pingtung Plain, Taiwan. In Recharge Systems for Protecting and Enhancing Groundwater Resources, Proceedings of the 5th International Symposium on Management of Aquifer Recharge, ISMAR5, Berlin, Germany, 11-16 June 2005; UNESCO: Paris, France, 2006; pp. 747-754.

182. Hashemi, H.; Berndtsson, R.; Persson, M. Artificial recharge by floodwater spreading estimated by water balances and groundwater modelling in arid Iran. Hydrol. Sci. J. 2015, 60, 336-350. [CrossRef]

183. Lundh, M.; Jonasson, S.A.; Jorgensen, N.O.; Johnson, M.D. Hydrogeology and water treatment performance of the Dösebacka artificial recharge plant-The basis for an efficient system for early warning. In Recharge Systems for Protecting and Enhancing Groundwater Resources, Proceedings of the 5th International Symposium on Management of Aquifer Recharge, ISMAR5, Berlin, Germany, 11-16 June 2005; UNESCO: Paris, France, 2006; pp. 825-832.

184. Tompson, A.F.B.; Carle, S.F.; Rosenberg, N.D.; Maxwell, R.M. Analysis of groundwater migration from artificial recharge in a large urban aquifer: A simulation perspective. Water Resour. Res. 1999, 35, 2981-2998. [CrossRef]

185. Vandenbohede, A.; Van Houtte, E.; Lebbe, L. Groundwater flow in the vicinity of two artificial recharge ponds in the Belgian coastal dunes. Hydrogeol. J. 2008, 16, 1669-1681. [CrossRef]

186. Vandenbohede, A.; Van Houtte, E. Heat transport and temperature distribution during managed artificial recharge with surface ponds. J. Hydrol. 2012, 472-473, 77-89. [CrossRef]

187. Pauw, P.S.; van Baaren, E.S.; Visser, M.; de Louw, P.G.B.; Essink, G.H.P.O. Increasing a freshwater lens below a creek ridge using a controlled artificial recharge and drainage system: A case study in The Netherlands. Hydrogeol. J. 2015, 23, 1415-1430. [CrossRef]

188. Pettenati, M.; Picot-Colbeaux, G.; Thiéry, D.; Boisson, A.; Alazard, M.; Perrin, J.; Dewandel, B.; Maréchal, J.C.; Ahmed, S.; Kloppmann, W. Water Quality Evolution During Managed Aquifer Recharge (MAR) in Indian Crystalline Basement Aquifers: Reactive Transport Modeling in the Critical Zone. Procedia Earth Planet. Sci. 2014, 10, 82-87.

189. Jensen, T.Ø.; Berg, R.L.; Bennedsen, L.; Brandt, G.; Spliid, H. Geochemical and microbial processes in the unsaturated zone at the Arrenæs artificial recharge trial plant. In Recharge Systems for Protecting and Enhancing Groundwater Resources, Proceedings of the 5th International Symposium on Management of Aquifer Recharge, ISMAR5, Berlin, Germany, 11-16 June 2005; UNESCO: Paris, France, 2006; pp. 115-120.

190. Abel, C.D.T. Soil Aquifer Treatment: Assessment and Applicability of Primary Effluent Reuse in Developing Countries. Ph.D. Thesis, Delft University of Technology, Delft, The Netherlands, 2014.

191. Vandenbohede, A.; Wallis, I.; Van Houtte, E.; Van Ranst, E. Hydrogeochemical transport modeling of the infiltration of tertiary treated wastewater in a dune area, Belgium. Hydrogeol. J. 2013, 21, 1307-1321. [CrossRef]

192. Azaroual, M.; Pettenati, M.; Casanova, J.; Besnard, K.; Rampnoux, N. Challenges of Artificial Recharge of Aquifers: Reactive Transport Through Soils, Fate of Pollutants and Possibility of the Water Quality Improvement. In Water Security in the Mediterranean Region; Scozzari, A., El Mansouri, B., Eds.; Springer: Dordrecht, The Netherlands, 2011; pp. 111-128.

193. Azaroual, M.; Thiéry, D.; Amraoui, N.; Pettenati, M.; Croiset, N.; Casanova, J.; Besnard, K.; Rampnoux, N. Physical, geochemical and microbial processes induced during the aquifer recharge using treated wastewaters: Laboratory and pilot experiments and numerical simulations. In Achieving Groundwater Supply Sustainability \& Reliability through Managed Aquifer Recharge, Proceedings of the 7th International Symposium on Managed Aquifer Recharge, ISMAR7, Abu Dhabi, UAE, 9-13 October 2009; Draeger, M., Ed.; 2012; pp. 170-177. Available online: http:/ / www.dina-mar.es/pdf/ismar7-proceedingsbook.pdf (accessed on 2 December 2016).

194. Goren, O. Geochemical Evolution and Manganese Mobilization in Organic Enriched Water Recharging Calcareous-Sandstone Aquifier; Clues from the Shafdan Sewage Treatment Plant. Ph.D. Thesis, Hebrew University, Jerusalem, Israel, 2009.

195. Hasan, I.; Sallwey, J.; Sandhu, C.; Fichtner, T.; Graeber, P.W. Simulation of water and solute transport in unsaturated soils by taking the example of decentralised treated wastewater infiltration. In Proceedings of AquaConSoil Conference, Barcelona, Spain, 16-19 April 2013. 
196. Greskowiak, J.; Prommer, H.; Massmann, G.; Nützmann, G. Modeling the redox-dependent fate of a pharmaceutically active compound during managed aquifer recharge. In Management of Aquifer Recharge for Sustainability, Proceedings of the 6th International Symposium on Managed Artificial Recharge of Groundwater, ISMAR6, Phoenix, AZ, USA, 28 October-2 November 2007; Fox, P., Ed.; Acacia Publishing: Phoenix, AZ, USA, 2007; pp. 220-230.

197. Nham, H.T.T.; Greskowiak, J.; Nödler, K.; Rahman, M.A.; Spachos, T.; Rusteberg, B.; Massmann, G.; Sauter, M.; Licha, T. Modeling the transport behavior of 16 emerging organic contaminants during soil aquifer treatment. Sci. Total Environ. 2015, 514, 450-458. [CrossRef] [PubMed]

198. Toze, S.; Bekele, E.; Page, D.; Sidhu, J.; Shackleton, M. Use of static Quantitative Microbial Risk Assessment to determine pathogen risks in an unconfined carbonate aquifer used for Managed Aquifer Recharge. Water Res. 2010, 44, 1038-1049. [CrossRef] [PubMed]

199. Hutchinson, A.S.; Milczarek, M. Banerjee Clogging Phenomena Related to Surface Water Recharge Facilities. In Clogging Issues Associated with Managed Aquifer Recharge Methods; Martin, R., Ed.; International Association of Hydrogeologists: Reading, UK, 2013; pp. 95-106.

200. Stuyfzand, P.J. Modelling the accumulation rate and chemical composition of clogging sludge layers in recharge basins with Easy-Leacher 4.6. In Management of Aquifer Recharge for Sustainability, Proceedings of the 4th International Symposium on Artificial Recharge of Groundwater, ISAR-4, Adelaide, Australia, 22-26 September 2002; Dillon, P., Ed.; A.A. Balkema: Lisse, The Netherlands, 2002; pp. 221-224.

201. Phipps, D.W.; Lyon, S.; Hutchinson, A.S. Development of a percolation decay model to guide future optimization of surface water recharge basins. In Management of Aquifer Recharge for Sustainability, Proceedings of the 6th International Symposium on Managed Artificial Recharge of Groundwater, ISMAR6, Phoenix, AZ, USA, 28 October-2 November 2007; Fox, P., Ed.; Acacia Publishing: Phoenix, AZ, USA, 2007; pp. 433-446.

202. Grützmacher, G.; Bartel, H.; Wiese, B. Simulating bank filtration and artificial recharge on a technical scale. In Recharge Systems for Protecting and Enhancing Groundwater Resources, Proceedings of the 5th International Symposium on Management of Aquifer Recharge, ISMAR5, Berlin, Germany, 11-16 June 2005; UNESCO: Paris, France, 2006; pp. 498-503.

203. Browne, D.; Deletic, A.; Fletcher, T.; Mudd, G. Modeling the development and consequences of clogging for stormwater infiltration trenches. In Proceedings of the 12th International Conference on Urban Drainage, Porto Alegre, Brazil, 11-16 September 2011.

204. Bekele, E.B.; Toze, S.; Rümmler, J.; Hanna, J.; Blair, P.; Turner, N. Improvements in wastewater quality from soil and aquifer passage using infiltration galleries: Case study in Western Australia. In Recharge Systems for Protecting and Enhancing Groundwater Resources, Proceedings of the 5th International Symposium on Management of Aquifer Recharge, ISMAR5, Berlin, Germany, 11-16 June 2005; UNESCO: Paris, France, 2006; pp. 663-668.

205. McMahon, G.A.; Arunakumaren, N.J.; Bajracharya, K. Hydrogeological Conceptualisation of the Burdekin River Delta. In Proceedings of the Hydro 2000: Interactive Hydrology, Perth, Australia, 20-23 November 2000.

206. Vidanaarchchi, C.K.; Zhou, Y.; Nonner, J.C.; Meijer, S.E. Optimisation of artificial groudnwater recharge system with infiltration galleries. In Artificial recharge of groundwater, Proceedings of the Third International Symposium on Artificial Recharge of Groundwater, TISAR 98, Amsterdam, The Netherlands, 21-25 September 1998; Peters, J.H., Ed.; A.A. Balkema: Rotterdam; Brookfield, 1998; pp. 161-166.

207. Russo, T.A.; Fisher, A.T.; Lockwood, B.S. Assessment of Managed Aquifer Recharge Site Suitability Using a GIS and Modeling. Groundwater 2015, 53, 389-400. [CrossRef] [PubMed]

208. Heilweil, V.M.; Benoit, J.; Healy, R.W. Variably saturated groundwater modelling for optimizing managed aquifer recharge using trench infiltration. Hydrol. Process. 2015, 29, 3010-3019. [CrossRef]

209. Hu, H.; Mao, X.; Barry, D.A.; Liu, C.; Li, P. Modeling reactive transport of reclaimed water through large soil columns with different low-permeability layers. Hydrogeol. J. 2015, 23, 351-364. [CrossRef]

210. Wang, S.; Tang, C.; Song, X.; Wang, Q.; Zhang, Y.; Yuan, R. The impacts of a linear wastewater reservoir on groundwater recharge and geochemical evolution in a semi-arid area of the Lake Baiyangdian watershed, North China Plain. Sci. Total Environ. 2014, 482-483, 325-335. [CrossRef] [PubMed] 
211. Rahman, M.A.; Ptak, T.; Nödler, K.; Licha, T.; Dimitriadis, K.; Soupilas, A.; Sauter, M. Influence of aquifer properties on water quality changes during infiltration of treated effluent. In Achieving Groundwater Supply Sustainability $\mathcal{E}$ Reliability through Managed Aquifer Recharge, Proceedings of the 7th International Symposium on Managed Aquifer Recharge, ISMAR7, Abu Dhabi, UAE, 9-13 October 2009; Draeger, M., Ed.; 2012; pp. 19-26. Available online: http://www.dina-mar.es/pdf/ismar7-proceedingsbook.pdf (accessed on 2 December 2016).

212. Nishikawa, T.; Densmore, J.N.; Martin, P.; Matti, J. Evaluation of the Source and Transport of High Nitrate Concentrations in Ground Water, Warren Subbasin, California; Water Resources Investigations Report 03-4009; U.S. Geological Survey: Sacramento, CA, USA, 2003.

213. Van Hoorick, M.; Feyen, J.; Pussemier, I. Experimental and numerical analysis of atrazine behaviour in an artifical recharge site. In Artificial Recharge of Groundwater, Proceedings of the Third International Symposium on Artificial Recharge of Groundwater, TISAR 98, Amsterdam, The Netherlands, 21-25 September 1998; Peters, J.H., Ed.; A.A. Balkema: Rotterdam, The Netherlands, 1998; pp. 401-403.

214. Stuyfzand, P.J.; Kortleve, M.; Olsthoorn, T.N.; Rolf, H. Accumulation and leaching during artificial recharge compared to a natural recharge system in The Netherlands. In Management of Aquifer Recharge for Sustainability, Proceedings of the 6th International Symposium on Managed Artificial Recharge of Groundwater, ISMAR6, Phoenix, AZ, USA, 28 October-2 November 2007; Fox, P., Ed.; ISMAR Proceedings; Acacia Publishing: Phoenix, AZ, USA, 2007; pp. 174-184.

215. Zare, M.; Koch, M. 3D-groundwater flow modeling of the possible effects of the construction of an irrigation/drainage network on water logging in the Miandarband plain, Iran. Basic Res. J. Soil Environ. Sci. 2014, 2, 2345-4090.

216. Hashemi, H.; Berndtsson, R.; Kompani-Zare, M.; Persson, M. Natural vs. artificial groundwater recharge, quantification through inverse modeling. Hydrol. Earth Syst. Sci. 2013, 17, 637-650. [CrossRef]

217. Gore, K.P.; Gurunadharao, V.V.S.; Naik, B.S.; Barman, D. Ground water recharge in Wagarwadi watershed through recharge process and ground water flow models. In Proceedings of the XVIIth World Congress of the International Commission of Agricultural and Biosystems Engineering (CIGR), Québec City, QC, Canada, 13-17 June 2010.

218. Flint, A.L. The Role of Unsaturated Flow in Artificial Recharge Projects. In Proceedings of the U.S. Geological Survey Artificial Recharge Workshop, Denver, CO, USA, 2-4 April 2002.

219. Wett, B. Monitoring Clogging of a RBF-System at the river Enns, Austria. In Riverbank Filtration Hydrology; Hubbs, S., Ed.; Nato Science Series: IV: Earth and Environmental Sciences; Springer: Dordrecht, The Netherlands, 2006; pp. 155-177.

220. Henzler, A.F.; Greskowiak, J.; Massmann, G. Modeling the fate of organic micropollutants during river bank filtration (Berlin, Germany). J. Contam. Hydrol. 2014, 156, 78-92. [CrossRef] [PubMed]

221. Wiese, B.; Nützmann, G. Hydraulic and transport modelling of bank filtration at Lake Tegel (Berlin). In Recharge Systems for Protecting and Enhancing Groundwater Resources, Proceedings of the 5th International Symposium on Management of Aquifer Recharge, ISMAR5, Berlin, Germany, 11-16 June 2005; UNESCO: Paris, France, 2006; pp. 449-454.

222. Sharma, S.K.; Chaweza, D.; Bosuben, N.; Holzbecher, E.; Amy, G. Framework for Feasibility Assessment and Performance Analysis of Riverbank Filtration Systems for Water Treatment. In Achieving Groundwater Supply Sustainability \& Reliability through Managed Aquifer Recharge, Proceedings of the 7th International Symposium on Managed Aquifer Recharge, ISMAR7, Abu Dhabi, UAE, 9-13 October 2009; Draeger, M., Ed.; 2012; pp. 398-405. Available online: http://www.dina-mar.es/pdf/ismar7-proceedingsbook.pdf (accessed on 2 December 2016).

223. Ray, C.; Prommer, H. Clogging-Induced Flow and Chemical Transport Simulation in Riverbank Filtration Systems. In Riverbank Filtration Hydrology; Hubbs, S., Ed.; Nato Science Series: IV: Earth and Environmental Sciences; Springer: Dordrecht, The Netherlands, 2006; Volume 60, pp. 155-177.

224. Schafer, C. Use of aquifer testing and groundwater modeling to evaluate aquifer/river hydraulics at Louisville Water Company, Lousville, Kentucky, USA. In Riverbank Filtration Hydrology; Hubbs, S., Ed.; Nato Science Series: IV: Earth and Environmental Sciences; Springer: Dordrecht, The Netherlands, 2006; pp. 179-198. 
225. Licht, E.; Herberer, T.; Wiese, B.; Grützmacher, G. Estimating of the solute transport parameters retardation factor and decay coefficient of pharmaceutical residues using the program visual CXTFIT. In Recharge Systems for Protecting and Enhancing Groundwater Resources, Proceedings of the 5th International Symposium on Management of Aquifer Recharge, ISMAR5, Berlin, Germany, 11-16 June 2005; UNESCO: Paris, France, 2006; pp. 399-403.

226. Eckert, P.; Rohns, H.P.; Irmscher, R. Dynamic processes during bank filtration and their impact on raw water quality. In Recharge Systems for Protecting and Enhancing Groundwater Resources, Proceedings of the 5th International Symposium on Management of Aquifer Recharge, ISMAR5, Berlin, Germany, 11-16 June 2005; UNESCO: Paris, France, 2006; pp. 17-22.

227. Horner, C.; Holzbecher, E.; Nützmann, G. A coupled transport and reaction model for long column experiments simulating bank filtration. In Recharge Systems for Protecting and Enhancing Groundwater Resources, Proceedings of the 5th International Symposium on Management of Aquifer Recharge, ISMAR5, Berlin, Germany, 11-16 June 2005; UNESCO: Paris, France, 2006; pp. 384-387.

228. Fritz, B.; Sievens, J.; Eichhorn, S.; Pekdeger, A. Geochemical and hydraulic investigations of river sediments in a bank filtration system. In Management of Aquifer Recharge for Sustainability, Proceedings of the 4th International Symposium on Artificial Recharge of Groundwater, ISAR-4, Adelaide, Australia, 22-26 September 2002; Dillon, P., Ed.; A.A. Balkema: Lisse, The Netherlands, 2002; pp. 95-100.

229. Gore, K.P.; Pendke, M.S.; Gurunadha Rao, V.V.S.; Gupta, C.P. Groundwater modelling to quantify the effect of water harvesting structures in Wagarwadi watershed, Parbhani district, Maharashtra, India. Hydrol. Process. 1998, 12, 1043-1052. [CrossRef]

230. Samma, D.; Xu, Y.; Christelis, G.; Church, J. Optimisation of water release from a dam to recharge a downstream unconfined alluvial aquifer. In Achieving Groundwater Supply Sustainability \& Reliability through Managed Aquifer Recharge, Proceedings of the 7th International Symposium on Managed Aquifer Recharge, ISMAR7, Abu Dhabi, UAE, 9-13 October 2009; Draeger, M., Ed.; 2012; pp. 78-84. Available online: http:/ /www.dinamar.es/pdf/ismar7-proceedingsbook.pdf (accessed on 2 December 2016).

231. Marston, T.M.; Heilweil, V.M. Numerical Simulation of Groundwater Movement and Managed Aquifer Recharge from Sand Hollow Reservoir, Hurricane Bench Area, Washington County, Utah; Scientific Investigations Report 2012-5236; U.S. Geological Survey: Reston, VA, USA, 2012.

232. Bhola, P.K.; Zabel, A.K.; Rajaveni, S.P.; Indu, S.N.; Monninkhoff, B.; Elango, L. Integrated surface water and groundwater modeling for optimizing MAR structures in the Chennai region. In Proceedings of the 8th Annual International Symposium on Managed Aquifer Recharge, ISMAR8, Beijing, China, 15-19 October 2013.

233. Narayan, K.A.; Schleeberger, C.; Bristow, K.L. Modelling seawater intrusion in the Burdekin Delta Irrigation Area, North Queensland, Australia. Agric. Water Manag. 2007, 89, 217-228. [CrossRef]

234. Zheng, F.; Liu, L.; Li, B.; Yang, Y.; Guo, M. Effects of Reclaimed Water Use for Scenic Water on Groundwater Environment in a Multilayered Aquifer System beneath the Chaobai River, Beijing, China: Case Study. J. Hydrol. Eng. 2015, 20, B5014003. [CrossRef]

235. Neumann, I.; Barker, J.; Macdonald, D.; Gale, I. Approximating technical effectiveness of low technology aquifer recharge structures using simple numerical solutions. In Recharge Systems for Protecting and Enhancing Groundwater Resources, Proceedings of the 5th International Symposium on Management of Aquifer Recharge, ISMAR5, Berlin, Germany, 11-16 June 2005; UNESCO: Paris, France, 2006; pp. 204-209.

236. Glushchenko, A.; Michaelsen, O.; Larsen, J.W.; Vasin, S.A.; Grünheid, S.; Hart, S.D.; Fritz, B. Kaliningrad Water Services Improvement Project-Baseline investigation for potential for reduction and stabilisation of organic matter. In Recharge Systems for Protecting and Enhancing Groundwater Resources, Proceedings of the 5th International Symposium on Management of Aquifer Recharge, ISMAR5, Berlin, Germany, 11-16 June 2005; UNESCO: Paris, France, 2006; pp. 29-36.

237. Sayit, A.P.; Yazicigil, H. Assessment of artificial aquifer recharge potential in the Kucuk Menderes River Basin, Turkey. Hydrogeol. J. 2012, 20, 755-766. [CrossRef]

238. Karimov, A.; Smakhtin, V.; Mavlonov, A.; Gracheva, I. Water "banking" in Fergana valley aquifers-A solution to water allocation in the Syrdarya river basin? Agric. Water Manag. 2010, 97, 1461-1468. [CrossRef]

239. Government of India. Manual on Artificial Recharge of Ground Water; Government of India, Ministry of Water Resources, Central Ground Water Board: Faridabad, India, 2007. 
240. Norma Official Mexicana. NOM-014-CONAGUA-2007 Requisitos Para la Recarga Artificial de Aquiferos con Agua Residual Tratada (Mexican Official Norm NOM-014-CONAGUA-2007, Requisites for the Artificial Recharge of Aquifers Using Treated Wastewater); Diario Oficial De La Federación: Mexico City, Mexico, 2008.

241. Maliva, R.G. Managed aquifer recharge: State-of-the-art and opportunities. Water Sci. Technol. Water Supply 2015, 15, 578-588. [CrossRef]

242. Wu, J.; Zeng, X. Review of the uncertainty analysis of groundwater numerical simulation. Chin. Sci. Bull. 2013, 58, 3044-3052. [CrossRef]

243. Doherty, J. Calibration and Uncertainty Analysis for Complex Environmental Models; Watermark Numerical Computing: Brisbane, Australia, 2015.

244. Poeter, E.P.; Hill, M.C.; Lu, D.; Tiedeman, C.R.; Mehl, S. UCODE_2014, with New Capabilities to Define Parameters Unique to Predictions, Calculate Weights Using Simulated Values, Estimate Parameters with SVD, Evaluate Uncertainty with MCMC, and More GWMI. Available online: http://igwmc.mines.edu/ freeware/ucode/UCODE_2014_User_Manual-version02.pdf (accessed on 6 December 2016).

245. California Department of Drinking Water. Groundwater Replenishment Using Recycled Water; California State Water Resources Control Board, Division of Drinking Water: Sacramento, CA, USA, 2014.

(C) 2016 by the authors; licensee MDPI, Basel, Switzerland. This article is an open access article distributed under the terms and conditions of the Creative Commons Attribution (CC-BY) license (http://creativecommons.org/licenses/by/4.0/). 